\title{
Mineralocorticoid regulation of cell function: the role of rapid signalling and gene transcription pathways
}

\author{
Gregory S Y Ong 1,2 and Morag J Young1,3 \\ ${ }^{1}$ Cardiovascular Endocrinology Laboratory, Centre for Endocrinology and Metabolism, Hudson Institute \\ of Medical Research, Clayton, Victoria, Australia \\ 2Department of Medicine, School of Clinical Sciences, Monash University, Clayton, Victoria, Australia \\ 3Department of Physiology, School of Biomedical Sciences, Monash University, Clayton, Victoria, Australia
}

Correspondence

should be addressed

to $M J$ Young

Email

morag.young@hudson.org.au

\begin{abstract}
The mineralocorticoid receptor (MR) and mineralocorticoids regulate epithelial handling of electrolytes, and induces diverse effects on other tissues. Traditionally, the effects of MR were ascribed to ligand-receptor binding and activation of gene transcription. However, the MR also utilises a number of intracellular signalling cascades, often by transactivating unrelated receptors, to change cell function more rapidly. Although aldosterone is the physiological mineralocorticoid, it is not the sole ligand for MR. Tissue-selective and mineralocorticoid-specific effects are conferred through the enzyme $11 \beta$-hydroxysteroid dehydrogenase 2 , cellular redox status and properties of the MR itself. Furthermore, not all aldosterone effects are mediated via MR, with implication of the involvement of other membrane-bound receptors such as GPER. This review will describe the ligands, receptors and intracellular mechanisms available for mineralocorticoid hormone and receptor signalling and illustrate their complex interactions in physiology and disease.
\end{abstract}

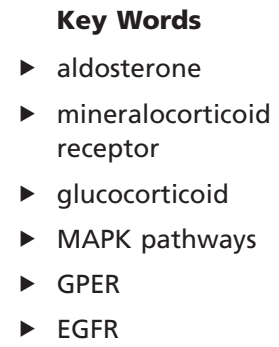

Journal of Molecular Endocrinology (2017) 58, R33-R57

\section{Introduction}

The mineralocorticoid receptor (NR3C2, henceforth abbreviated MR) and mineralocorticoids regulate numerous physiological processes including control of electrolytes, extracellular volume and blood pressure (Waldinger et al. 1977), intracellular pH (Oberleithner et al. 1987), cardiac action potentials (Lalevee et al. 2005, Boixel et al. 2006) and vascular function (Liu et al. 2003, Uhrenholt et al. 2003, Gros et al. 2013) among others. The MR also contributes to cardiovascular and renal disease. Primary hyperaldosteronism (PA), a cause of secondary hypertension due to chronic excessive aldosterone synthesis, is associated with increased mortality and morbidity independent of the degree of hypertension (Milliez et al. 2005).
The MR can change cell function through multiple means. Edelman first proposed that aldosterone modifies sodium transport via gene transcription (Edelman et al. 1963), a mechanism recently confirmed as critical for life-sustaining salt homeostasis (Cole et al. 2015). MR activation also triggers rapid responses that are impervious to transcription inhibitors, suggesting a nongenomic action (Moura \& Worcel 1984, Le Moellic et al. 2004). Furthermore, mineralocorticoids may activate receptors other than the 'classic' cytosolic MR: either as a ligand of a different cell membrane-associated receptor, or by influencing signalling of unrelated receptors such as angiotensin II receptor 1 (AGTR1). These systems do not occur in isolation, and may enable, complement,

Published by Bioscientifica Ltd 
augment or abrogate each other. Given the complexity at several levels, the purpose of this review is to identify the key mechanisms of mineralocorticoid action and characterise their actions and contribution to physiology and disease.

\section{The structure and function of the MR}

In humans, the MR is part of a steroid-activated transcription factor superfamily and retains significant structural similarities to the glucocorticoid receptor (NR3C1, henceforth abbreviated GR) and progesterone receptor (PGR) (Arriza et al. 1987). All nuclear receptors contain an amino terminal domain (NTD), DNAbinding domain (DBD), hinge region and a ligandbinding domain (LBD). The MR and other steroid hormone receptors are activated through ligand-LBD interaction, but other parts of their structure can affect outcomes. The NTD, via its activation function-1 (AF-1a and AF-1b) sites, interact with nuclear proteins, and, together with AF-2 sites in the LBD, can bind co-regulatory molecules which serve to modify transcriptional function (Pippal \& Fuller 2008).

In the basal or unliganded state, the MR is located predominantly in the cytosol (Rogerson et al. 2004) as part of a heterocomplex with chaperone heat shock proteins (HSPs) such as HSP90, immunophilins (such as FKBP52) and protein phosphatase 5 (Galigniana et al. 2010a, Huyet et al. 2012). HSP90 facilitates ligand binding to MR, while FKBP52 is important in cytoplasmic-nuclear shuttling of MR after ligand binding (Galigniana et al. $2010 b$ ). Once in the nucleoplasm, the MR dissociates from its chaperones to allow binding to DNA (Galigniana et al. 2010a) and forms dimers (Nishi et al. 2004, Grossmann et al. 2012). The MR not only forms homodimers, but also heterodimerises with GR, resulting in different transcriptional responses. The degree of heterodimerisation depends on the relative abundance of activated MR and GR, which is influenced by hormone availability, cell-specific steroid handling and receptor expression (Nishi et al. 2004, Ackermann et al. 2010, Nishi 2011).

The MR DBD binds to specific DNA sequences, known as hormone response elements (HREs), to regulate transcription of target genes (Fig. 1, section A). The HREs could also bind GR; they were originally described in that context (Payvar et al. 1983). The crystal structure of the MR DBD when bound to a HRE is similar to that for the GR (Hudson et al. 2014). The HRE structure allows each receptor in the dimer to bind to a 'half-site' of the palindromic consensus sequence (Nishi et al. 2004, Grossmann et al. 2012). In many HREs, sequences adjacent to the consensus motifs facilitate binding of non-hormone transcription factors such as activated protein-1 (AP-1), early growth response protein 1 (EGR1), forkhead box (FOX) and paired box protein 5 (PAX5) (Pearce \& Yamamoto 1993, Le Billan et al. 2015). Interaction with co-factors at the NTD may explain some of the differences in gene regulation between MR and GR despite the overlap in ligand binding, receptor structure and target DNA sequence recognition (Pearce \& Yamamoto 1993, Lim-Tio et al. 1997). Some HREs can preferentially enhance transcription in response to MR than GR (Kolla et al. 1999), or may only bind MR specifically (Meinel et al. 2013b). As the MR can bind to many areas of DNA which lack a partial or full classical HRE sequence, HREs are not mandatory for MR genomic regulation. Instead, MR may form complexes with other transcription factors that have known binding sites in these HRE-free regions, rather than directly binding DNA itself (Le Billan et al. 2015).

\section{Pre-receptor and receptor mechanisms determining ligand-specific effects of MR}

Aldosterone is the major physiological mineralocorticoid and its importance is demonstrated by the neonatal onset of life-threatening salt wasting and hyperkalaemia when it is deficient (Daughaday \& Rendleman 1967, Hui et al. 2014). Aldosterone is synthesised in the zona glomerulosa of the adrenal gland under the regulation of the renin-angiotensin system (RAS), extracellular potassium levels and adrenocorticotropic hormone (ACTH). Its function in regulating salt and fluid balance is achieved by altering the sodium transport machinery of renal tubular epithelial cells (Loffing \& Korbmacher 2009) and is critical for protection against hypovolaemia (Fine et al. 1958, Beuschlein 2013).

Apart from aldosterone, the human MR has high affinity for the glucocorticoids cortisol and corticosterone (Pearce \& Funder 1988), and the sex steroid progesterone (Quinkler et al. 2002). This may be a vestige of evolution, with progression from a single multifunctional corticosteroid receptor (CR) in primitive marine animals to distinct mineralocorticoid and glucocorticoid hormones and receptors in higherorder land animals (Baker et al. 2013). Given that glucocorticoids are substantially more abundant than mineralocorticoids in the circulation and intracellular fluid, mechanisms must exist to confer specificity of

Published by Bioscientifica Ltd. 


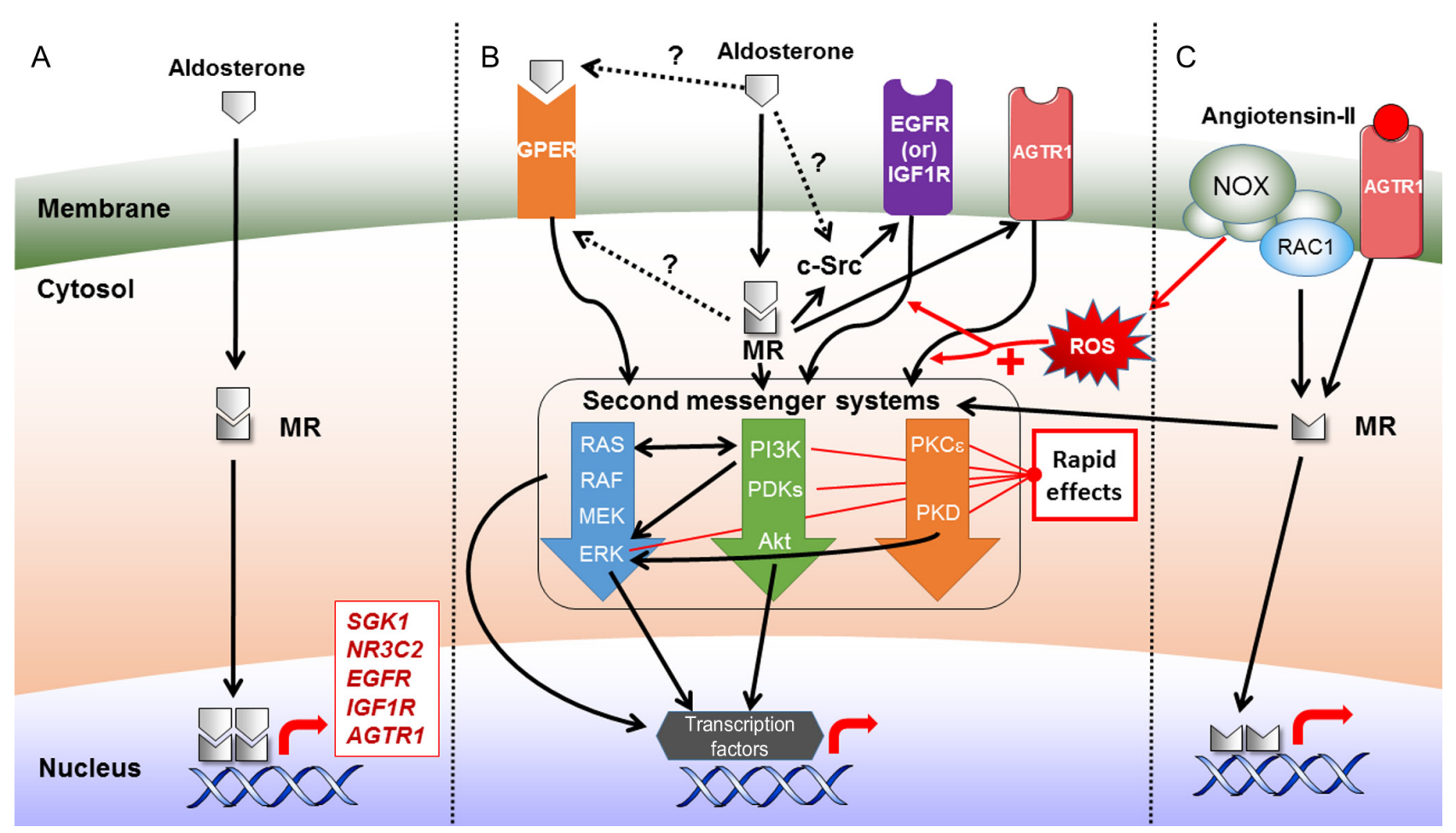

\section{Figure 1}

Overview of the cellular responses to MR activation. (A) Once activated, the mineralocorticoid receptor (MR) translocates to the nucleus and transcribes target genes including SGK1, sodium channel subunits and receptors such as the MR gene (NR3C2), epidermal growth factor receptor (EGFR), insulin-like growth factor 1 receptor (IGF1R) and angiotensin II receptor 1 (AGTR1). Some gene targets are intermediaries that activate other transcription factors. (B) Alternatively, aldosterone and MR act via second messenger systems, often by activating unrelated receptors in the absence of their ligands. Note, the MR may also signal via other MAPK cascades (JNK and p38MAPK) but only the ERK cascade is shown here. Additionally, aldosterone may act in an MR independent manner - potentially by directly binding to and activating unknown membrane receptors instead. GPER is one such proposed receptor, although MR binding to it has not been definitively demonstrated. (C) RAC1 and AGTR1 can also activate MR signalling and gene transcription in certain circumstances, in the absence of any ligand binding to MR. Some signalling pathways are redox sensitive and enabled or enhanced by NADPH oxidase (NOX) production of reactive oxygen species (ROS).

effect at the MR. The enzyme 11-beta-hydroxysteroid dehydrogenase type 2 (HSD11B2) is co-expressed with MR in epithelial cells, metabolising cortisol to cortisone, which cannot bind or activate the MR (Funder et al. 1988). This is crucial for the specificity of aldosterone as the regulator of fluid homeostasis. If HSD11B2 is deficient or inhibited, hypertension and hypokalaemia develop due to cortisol activation of renal MR (Koster \& David 1968, Dave-Sharma et al. 1998, Mullins et al. 2015). In the vasculature, endothelial cells can express HSD11B2 (Brem et al. 1998, Christy et al. 2003, Gong et al. 2008), while the literature is conflicting regarding its presence in vascular smooth muscle cells (VSMCs) (Hatakeyama et al. 2001, Christy et al. 2003). Deficiency or inhibition of HSD11B2 impairs endothelium-mediated vasodilation, but glucocorticoid occupation of MR may not be the cause (Christy et al. 2003, Sobieszczyk et al. 2010). Instead, a potential mechanism may involve regulation of endothelial nitric oxide synthase (eNOS) expression. Glucocorticoids inhibit eNOS transcription, which is exacerbated by HSD11B2 knockdown in a human umbilical vein endothelial cell (HUVEC) line (Liu et al. 2009).

Generally, in tissues where HSD11B2 is not expressed, glucocorticoids are the physiological ligand for the MR (Iqbal et al. 2014). An exception occurs where the related enzyme HSD11B1 is expressed, without co-expression of hexose-6-phosphate dehydrogenase (H6PD). H6PD generates the reduced form of nicotinamide adenine dinucleotide phosphate (NADPH), without which HSD11B1 shifts its role from reductase to dehydrogenase, metabolising cortisol to cortisone (Hewitt et al. 2005, Chen et al. 2014). Transgenic mice overexpressing HSD11B2 in cardiomyocytes develop dilated cardiomyopathy and fibrosis, which is attenuated with MR antagonism (Qin et al. 2003), implying that basal cardiac MR occupancy by endogenous glucocorticoid is protective against activation. However, in situations of 
intracellular oxidative stress, such as with inflammation or ischaemia, glucocorticoids can activate the MR (Rossier et al. 2008, Mihailidou et al. 2009). Therefore, the benefits of spironolactone or eplerenone in heart failure are not solely from aldosterone antagonism, but general blockade of MR (Pitt et al. 1999, 2003, Zannad et al. 2011). Hence, the availability of ligand, distribution of HSD11B2 expression and the redox status of cells determine the final response of the MR to ligand activation.

The intrinsic properties of the MR structure influence the outcome to ligand binding at the receptor. The MR LBD pocket shape and van der Waal forces between residues on the LBD and steroid determine ligand binding affinity and transcriptional activity (Li et al. 2005, Mani et al. 2016). After ligand binding, the MR changes conformation and recruits other elements to facilitate nuclear localisation and transcription (Yang \& Young 2009). Aldosterone remains bound to MR for a comparatively longer period than cortisol, which stabilises the MR in a conformation that can more effectively recruit co-regulators, resulting in aldosterone having greater potency than cortisol for inducing MR target gene transcription (Hellal-Levy et al. 2000, Gallo et al. 2007, Huyet et al. 2012). It is also possible for MR activation and nuclear translocation to occur without ligand binding. Ras-related C3 botulinum toxin substrate 1 (RAC1) is part of the Rho family of small GTPases, which regulate many cellular processes. Importantly, it is involved in ROS generation and can activate steroid hormone receptors including the MR (Shibata et al. 2008). RAC1 activation, with associated ligand-independent MR activation, can occur in the context of oxidative stress (Nagase et al. 2012) (Fig. 1, section C), salt loading in saltsensitive Dahl rats (Shibata et al. 2011), and in a transverse aortic constriction model of cardiac pressure overload (Ayuzawa et al. 2015). Further work is required to confirm these RAC1 mechanisms, and establish the molecular link with MR overactivity.

\section{How the activated MR changes cellular processes}

\section{Expression of MR target genes}

The MR utilises several mechanisms to effect cellular change. These mechanisms allow diversity in timing, duration, magnitude and context or nature of the effect (Fig. 1). MR regulates the transcription of many genes (Fig. 1, section A), with well-established MR targets being those related to electrolyte handling in renal epithelial tissues, such as sodium channels or transporters (Mick et al. 2001). Further candidate MR target genes are proposed through transcriptome analyses on renal, aortic and cardiac tissue after exposure to aldosterone. These have diverse functions in cell signal transduction, oxidative stress, inflammatory mediators, steroid biosynthesis, receptor chaperoning, cellular structure, adhesion and migration (Turchin et al. 2006, Latouche et al. 2010, Newfell et al. 2011, Ueda et al. 2014). Comparison between mice with cardiac overexpression of either GR or MR suggests that there is surprisingly little overlap in GR- and MR-regulated genes in the heart (Latouche et al. 2010). Novel genes identified in these experiments require further investigation to establish the mechanism and functional outcomes of their regulation by MR.

\section{Rapid signalling through second messenger systems}

Gene transcription and protein translation is a relatively slow process. A delay of several hours may transpire before any functional change, if protein synthesis, export, translocation and assembly is required (such as for membrane-based sodium channels). This would be inadequate when a rapid homeostatic response to acute disturbance is required, such as during haemorrhage. MR activation can trigger more rapid cellular events through non-genomic means. For instance, aldosterone increases epithelial sodium channel (ENaC) activity within 2 min (Zhou \& Bubien 2001), which is significantly faster than the 30 min required for mRNA expression of serum and glucocorticoid-regulated kinase 1 (SGK1), a 'rapidly' transcribed MR target gene (Naray-Fejes-Toth \& Fejes-Toth 2000). The MR is able to utilise second messenger systems to initiate these rapid effects (Fig. 1, section B).

Mitogen-associated protein kinases (MAPK) MAPKs are a group of serine/threonine cytoplasmic protein kinases, which catalyse phosphorylation and activation of proteins to regulate numerous diverse cellular processes. As a cascade of sequentially activated kinases, MAPK relays signals from the cell surface (e.g. from a membrane receptor) to the interior (Roskoski 2012). In mammals, the key families of MAPK are extracellular signal-regulated kinase (ERK), p38 kinase (p38 MAPK) and c-jun N-terminal kinase (JNK) all of which can be triggered by MR activation (Nagai et al. 2005, Han et al. 2009, Walczak et al. 2011). MAPK signalling is important for MR-mediated cell proliferation or apoptosis, such as in the developing neonatal rat kidney (Yim et al. 2009), and cellular electrolyte handling (Gekle et al. 2001,

Published by Bioscientifica Ltd. 
McEneaney et al. 2008). The ERK cascade (RAS-RAF-MEKERK) is rapidly activated within $2-5 \mathrm{~min}$ by aldosterone (Gekle et al. 2001, McEneaney et al. 2010a); JNK can similarly be activated within 5 min (Han et al. 2009), and p38 MAPK within 10 min (Lee et al. 2004). Initial rapid ERK1/2 activity lasts around $30 \mathrm{~min}$ (Nagai et al. 2005), but can be extended to around $2 \mathrm{~h}$ in a protein kinase D (PKD)dependent mechanism (McEneaney et al. 2010a), with further prolongation of the response to 4-6h requiring transcription of Kirsten Ras (K-Ras) mRNA (Hendron \& Stockand 2002). Less is known about prolonged activation of the other MAPK cascades by MR.

\section{Phosphatidylinositide lipid and protein kinase} messenger system Phosphatidylinositide 3-kinases (PI3K) activity is stimulated by aldosterone, which phosphorylates membrane phosphatidylinositol and generates phosphatidylinositol 3,4,5-trisphosphate (PIP3) (Blazer-Yost et al. 1999). PIP3 is required to activate phosphatidylinositol-dependent kinases (PDK) and ultimately Akt as the effector of PI3K-dependent cellular processes (Ghigo \& Li 2015). MR-dependent Akt phosphorylation occurs within $15 \mathrm{~min}$ of aldosterone exposure, suggesting that PI3K/Akt is a pathway for MR-mediated rapid effects (Huang et al. 2012) including electrolyte handling and vasomotor function.

Protein kinases C (PKC) and D PKC and PKD form part of a regulatory signalling cascade, commonly under the regulation of G-protein coupled surface receptors. Activation of the PKC $\varepsilon$ subtype leads to phosphorylation of PKD at two critical activating sites leading to downstream effects including membrane trafficking, cell survival, cell migration and interaction with MAPK cascades (Rozengurt et al. 2005). MR uses PKC and PKD signalling to alter electrolyte handling in renal epithelial cells and in cardiomyocytes (Mihailidou et al. 2004, McEneaney et al. 2008).

\section{Interaction with other hormone receptor systems}

The intracellular signalling cascades induced by MR activation are complex and intricately intertwined. Mapping discrete pathways linking MR to cellular outcomes is difficult due to the extent of cross-talk between the elements, and their occasionally opposing effects. This difficulty is further exacerbated when considering the involvement of other receptor systems in this process. In many cases, second messenger systems are not directly activated by MR. Instead the MR transactivates other receptors, which trigger downstream signalling similar to activation by their own ligand. Although these transactivated receptors share second messenger systems, their effects are not identical due to differences in receptor expression and the specific context required for activation (particularly redox status). These effects span the full time course of cellular events from rapid posttranslational modifications to slower gene transcription (Wang et al. 2001, Holzman et al. 2007, Cascella et al. 2010).

Epidermal growth factor receptor (EGFR) and platelet-derived growth factor receptor (PDGFR) The EGFR is a transmembrane receptor tyrosine kinase, which, along with structurally similar receptor tyrosine kinases such as HER2, ErbB3 and ErbB4, is part of the ErbB family. When activated, EGFR homodimerises or heterodimerises with another member of the ErbB family, triggering autophosphorylation of tyrosine residues in its cytoplasmic domains and activation of associated intracellular signalling cascades (Mirone et al. 2015). These include MAPK, Janus kinase/signal transducers and activators of transcription (JAK/STAT) and PI3K/Akt (Mirone et al. 2015). EGFR, a mediator of growth and repair, is a recognised contributor to renin-angiotensinaldosterone system (RAAS)-driven cardiac and renal fibrosis (Zhuang \& Liu 2014, Forrester et al. 2016). Aldosterone activates EGFR in a non-MR-dependent process within 10 min, triggering the ERK cascade and ultimately causing calcium influx and cellular alkalinisation through increased activity of the sodium/hydrogen exchanger (NHE)-1 (Gekle et al. 2002). Aldosterone activation of other multifunctional signalling pathways via EGFR, such as the JNK pathway (Grossmann et al. 2005) and PI3K/Akt (Huang et al. 2009), are MR dependent. The signalling process is influenced by the cellular redox state, in that the antioxidant $\mathrm{N}$-acetylcysteine (NAC) prevents downstream effects of aldosterone-MR transactivation of EGFR on PI3K (Huang et al. 2009).

As illustrated in Fig. 1 section B, the link between MR and EGFR activation is the non-receptor tyrosine kinase, c-Src, which phosphorylates a tyrosine residue at position 845 on EGFR (Grossmann et al. 2005, McEneaney et al. 2007). Aldosterone rapidly increases c-Src phosphorylation within $5 \mathrm{~min}$ and has maximal response at $30 \mathrm{~min}$ (Callera et al. 2005). Furthermore, c-Src activation by MR may be dependent on the PDGFR in a complex interaction occurring within cellular invaginations, termed caveolae. Here, the transactivation of PDGFR by MR facilitates translocation of c-Src to cholesterol-rich domains and its phosphorylation (Callera et al. 2011b). Another potential

Published by Bioscientifica Ltd. 
link is the G-protein coupled oestrogen receptor (GPER), which is required for MR-EGFR transactivation at least in one ER-negative breast cancer cell line (Rigiracciolo et al. 2016). Furthermore, there is a synergistic relationship between MR and the EGFR. As an MR target gene, EGFR expression is upregulated by MR activation (Krug et al. 2003, Meinel et al. 2013a). Conversely, EGFR activation of ERK1/2 signalling is an important facilitator of MR nuclear shuttling (Grossmann et al. 2005). These complementary events could potentiate EGFR-related signalling from prolonged MR activation.

Insulin-like growth factor-1 receptor (IGF1R) The IGF1R is ubiquitously expressed and is important in the regulation of cell growth mainly through MAPK signalling, and metabolism through PI3K/Akt signalling. Its primary ligand, IGF-1, is not only important as the effector protein of the growth hormone system, but is involved in cardiovascular function, insulin resistance and pancreatic beta islet cell function and malignancy (Abbas et al. 2008). Aldosterone induces phosphorylation of IGF1R within $10 \mathrm{~min}$ in renal and cardiac fibroblasts, and in renal epithelial cells (Bunda et al. 2007, Holzman et al. 2007, Chen et al. 2013). In fibroblasts, aldosterone does not require MR to transactivate IGF1R, but utilises c-Src as an intermediary (Chen et al. 2013). The activation of c-Src in fibroblasts may depend on a surface membrane G-protein coupled receptor, as siRNA knockdown of the G-protein subunit $\mathrm{G}_{13}$ prevented c-Src and IGF1R phosphorylation (Bunda et al. 2009). In renal epithelia, IGF1R transactivation requires MR, but the mechanism is not yet characterised (Holzman et al. 2007). As IGF-1 can mimic some aldosterone effects on renal sodium handling via PI3K, and can activate similar second messenger systems to MR, the IGF1R is a candidate intermediary for MR action (Blazer-Yost et al. 1999). IGF1R expression can be upregulated by MR, particularly in conditions of oxidative stress, with enhanced downstream signalling promoting VSMC growth, migration and protein synthesis (Cascella et al. 2010).

Angiotensin II receptor 1 (AGTR1) Angiotensin II is an important effector protein of the RAAS system and a major secretagogue for aldosterone. It acts primarily through two receptors: AGTR1 and AGTR2. AGTR1 is associated with classical functions ascribed to angiotensin II such as vasoconstriction, reactive oxygen species (ROS) generation, vascular cell proliferation, aldosterone production, salt/fluid retention and increased sympathetic activity. AGTR2 has opposing effects including vasodilation, nitric oxide (NO) generation and promotion of apoptosis (Vinturache \& Smith 2014). Both AGTR1 and MR play a role in rapid signalling triggered by mineralocorticoids and angiotensin II. In mouse mesenteric vessels, aldosterone-induced ERK activation and rapid vasoconstriction requires AGTR1, but is MR independent (Yamada et al. 2008, Lemarie et al. 2009). However, AGTR1 and MR are both required for activation of the nuclear factor kappa-light-chain-enhancer of activated B cells (NF-kB), a transcription complex which regulates numerous inflammatory genes (Lemarie et al. 2009). As angiotensin II also requires MR for NF- $\mathrm{kB}$ activation, the cross-talk between MR and AGTR1 is a common molecular signalling mechanism spanning both ligands (Lemarie et al. 2009). However, the nature of the MR-AGTR1 interaction varies between cell types: for example, in contrast to vascular cells, aldosteroneinduced ERK phosphorylation needs both MR and AGTR1 in cardiomyocytes (Cannavo et al. 2016).

In rodents, AGTR1 occurs as two subtypes ( $a$ and $b$ ) which have differing effects on downstream signalling pathways. In mouse mesenteric VSMCs, angiotensin II and aldosterone activation of ERK1/2 and JNK was AGTR1a but not AGTR1b or MR dependent, but both AGTR1 subtypes are needed for NF-kB activation (Lemarie et al. 2009). AGTR1a has also been identified as an important facilitator of aldosterone-mediated genomic effects. Knockout of AGTR1a reduces transcription of c-fos, a rapidly induced transcription factor, in response to aldosterone compared to wild type in VSMCs (Lemarie et al. 2009). The relevance of AGTR1 subtypes to humans is unclear, with little in the literature regarding their existence and whether they are analogous to the mouse subtypes (Konishi et al. 1994).

As with EGFR/PDGFR and IGF1R, c-Src is an important link between MR, AGTR1 and the ERK cascade (Cannavo et al. 2016). In fact, EGFR/PDGFR signalling with activation of c-Src can be triggered by synergism of angiotensin II and aldosterone at low doses that individually do not alter cell signalling. Downstream processes are also activated, such as generation of ROS by NADPH oxidase (NOX), translocation of RhoA/Rho kinase to the cell membrane, ROS-dependent activation of RhoA and finally VSMC migration (Montezano et al. 2008). Hence, in the correct environment and cell context, c-Src links MR and multiple other receptor signalling pathways. Apart from the contribution of c-Src, exactly how mineralocorticoids and the MR could transactivate AGTR1 is unknown. Aldosterone triggers dimerization of AGTR1, with the transglutaminase enzyme as a critical intermediary (Yamada et al. 2008); given

Published by Bioscientifica Ltd. 
that transglutaminase activity is calcium-dependent, aldosterone-induced calcium influx may be an early regulator of AGTR1 transactivation. It is not clear if this is an MR-dependent effect or not. Further research is needed to confirm this theory and to characterise the remaining components of the pathway.

The relationship among aldosterone, angiotensin II, MR and AGTR1 serves to mutually enhance the signalling of each individual ligand-receptor system. Aldosterone is able to upregulate the expression of both MR and AGTR1 (Schiffrin et al. 1985, Zennaro et al. 1996, Tsai et al. 2013). In cardiomyocytes, aldosterone control of MR expression is dependent on MR coupled to AGTR1 signalling and downstream ERK and JNK activation, whereas AGTR1 expression is regulated by MR-independent transactivation of AGTR1 signalling (Tsai et al. 2013). Furthermore, aldosterone activation of MR increases transcription of angiotensin-converting enzyme (ACE) mRNA in the aorta of rats treated with aldosterone (Hirono et al. 2007) and in cultured rat aortic endothelial cells (Sugiyama et al. 2005). This process is JAK2 dependent and requires downstream c-Src signalling and transactivation of EGFR. The resultant increase in local angiotensin II levels exacerbates endothelial dysfunction and damage (Sugiyama et al. 2005). ACE expression in cardiomyocytes is similarly enhanced by MR (Harada et al. 2001, Wang et al. 2002). However, the practical relevance of local ACE activity to vasomotor function is uncertain given that aldosteroneinduced mesenteric vasoconstriction ex vivo is not mitigated by ACE inhibition (Yamada et al. 2008).

In a bilateral relationship, angiotensin II can transactivate MR via AGTR1 and increase transcription of MR-dependent genes, a process that can be suppressed by spironolactone (Jaffe \& Mendelsohn 2005). AGTR1 transactivation of MR may involve RAC1, which is highly activated in a mouse model of salt and angiotensin II excess (Fig. 1, section C). In this scenario, RAC1 inhibition reduces MR nuclear localisation and SGK1 transcription to the same extent as eplerenone (Kawarazaki et al. 2012). Local production of aldosterone is not involved, as angiotensin II-treated VSMCs do not express aldosterone synthase and gene expression is not altered by aldosterone synthase inhibition (Jaffe \& Mendelsohn 2005). Conversely, MR acts via AGTR1 to upregulate profibrotic markers such as collagen 1A (COL1A) and 3A (COL3A) and $\alpha$-smooth muscle actin (SMA) (Tsai et al. 2013). Therefore, the MR and AGTR1 are intertwined at multiple points facilitating cooperation of different effector systems of RAAS with implications for both homeostasis and in disease states.
G-protein coupled oestrogen receptor (GPER, also known as GPER-1 or GPR30) As many cellular signalling cascades relay information from membrane surface to the interior, it was believed that a distinct membrane-bound MR exists. Radiolabelled binding assays showed mineralocorticoid binding to the plasma membrane of porcine renal cells and human monocytes with higher affinity than other steroids (Wehling et al. 1991, Christ et al. 1994). Furthermore, bovine serum albumin (BSA)-conjugated aldosterone triggers PKC $\alpha$ signalling (Le Moellic et al. 2004) and polyethylene glycol (PEG)-conjugated aldosterone activates ERK, despite both being too large to enter the cell to activate classical cytosolic MR (Ashton et al. 2015). Differential action of classical and alternative receptors is suggested by the latter study, where PEG-aldosterone could not upregulate classical MR target genes such as $S G K 1$, yet unconjugated aldosterone could both upregulate SGK1 and activate ERK. However, numerous experiments have failed to identify a unique membrane-bound MR. Instead, GPER is proposed as an alternative candidate for mineralocorticoid signalling.

GPER is a G-protein coupled receptor that is expressed in numerous tissues such as cardiomyocytes, VSMCs, vascular endothelium, lung, liver and reproductive tissues (Prossnitz et al. 2007, Jessup et al. 2010, Gros et al. 2011b). $17 \beta$-Oestradiol (E2) was the first known ligand for GPER, which is responsible for some of the rapid effects of E2 via MAPK (Filardo et al. 2000), and via PI3K signalling mediated by EGFR transactivation (Revankar et al. 2005). In GPER-transfected human embryonic kidney cells, which lack native oestrogen receptors, E2 exhibits rapid association/dissociation and high-affinity binding to the recombinant human GPER with a dissociation constant $\left(K_{\mathrm{d}}\right)$ of $2.7 \mathrm{nM}$ (Thomas et al. 2005). In an ex vivo experiment, E2 concentrations of $0.1-10 \mathrm{nM}$ are capable of inducing GPER-mediated changes to calcium handling in the renal connecting tubule (Hofmeister et al. 2012).

GPER may also be responsible for a subset of aldosterone's rapid cellular actions involving ERK signalling in rat aortic VSMCs (Gros et al. 2011b), endothelial cells (Gros et al. 2013) and rat H9C2 cardiomyocytes (Ashton et al. 2015). In these tissues, aldosterone activation of ERK could occur through either MR or GPER (Fig. 1, section B). Evidence for GPER signalling includes the maintenance of phosphorylation of ERK in rat endothelial tissue lacking MR (Gros et al. 2013), despite the eplerenone treatment in native GPER and MR expressing freshly isolated endothelium-denuded rat aorta (Gros et al. 2011b). Yet, ERK activation is inhibited
() 2017 Society for Endocrinology Printed in Great Britain
Published by Bioscientifica Ltd 
with GPER antagonism or knockdown (Gros et al. 2011b, Ashton et al. 2015). Where both GPER and MR are co-expressed, the relative contribution to aldosteronemediated ERK activation varies by cell type. In primary cultures of rat ventricular myocytes, GPER blockade inhibits ERK phosphorylation to a lesser degree than MR or AGTR1 antagonism, and does not affect MR-mediated ROS generation (Cannavo et al. 2016). Primary VSMC cultures tend to lose GPER expression over time, and in this context aldosterone can trigger ERK signalling via MR alone. However, when GPER is reintroduced through adenoviral transfection, MR predominantly acts through GPER (Gros et al. 2011b). There is ongoing debate as to whether aldosterone is a true ligand of GPER. Although there is apparent activation of GPER at physiological levels of aldosterone (e.g. $10 \mathrm{nM}$ ) in the above-mentioned studies, binding has not been definitively demonstrated (Cheng et al. 2014, Rigiracciolo et al. 2016). Alternative mechanisms of aldosterone action via GPER may include direct physical association between MR and GPER (Rigiracciolo et al. 2016), cross-talk via second messengers, GPER induction of local aldosterone synthase, and modification of the structural protein striatin, which can modulate steroid receptor function (Barton \& Meyer 2015). However, the persistence of aldosterone responses in tissues lacking or deficient in MR and blocked by GPER antagonist is not explained by these alternative hypotheses (Feldman \& Limbird 2015).

\section{NOX, ROS and MR signalling}

The MR activation of other membrane receptor signalling systems increases the diversity of its functions. These cross-talk interactions are necessarily context dependent to avoid non-specific activation. In particular, the redox status of cells is a major determinant of MR access to these alternative pathways. The generation of ROS is increased by MR activation, particularly through upregulation of NOX. NOX is a family of membrane-bound enzymes, which generate superoxide from NADPH and oxygen. NOX is present in leucocytes, where superoxide is required for the antimicrobial oxidative burst. It is also found in cardiomyocytes, endothelial cells and VSMCs (Ying 2008, Santillo et al. 2015). NOX-generated ROS has numerous regulatory functions including altering protein phosphorylation, enzymatic reactions, cellular ion transport, gene transcription, cell growth and death (Bedard \& Krause 2007). In disease, enhanced NOX activity leads to excessive and dysfunctional activation of proinflammatory, profibrotic and angiogenic genes through the AP-1 and NF-kB pathways (Fiebeler et al. 2001, Queisser et al. 2011). Many subtypes of NOX exist, but in experimental RAAS overactivation, NOX2 is upregulated in heart tissue whereas NOX1 and NOX4 are not. This suggests specific isoforms are responsible for RAASinduced cardiovascular oxidative stress and inflammation (Stas et al. 2007, Nakamura et al. 2009).

Aldosterone rapidly increases ROS generation by NOX within minutes in VSMCs (Callera et al. 2005) and cardiomyocytes (Hayashi et al. 2008, Tsai et al. 2010). The rapid onset of action and persistence of NOX generation of ROS, despite the inhibition of transcription and protein synthesis, strongly support a non-genomic mineralocorticoid contribution to regulation of NOX (Hayashi et al. 2008). The aldosterone effect is MR dependent in most studies (Callera et al. 2005, Hayashi et al. 2008, Iwashima et al. 2008), although one study using HL-1 atrial cardiomyocytes found no inhibitory effect of spironolactone (Tsai et al. 2010). MR activation of NOX is c-Src-dependent (Callera et al. 2005, Iwashima et al. 2008, Montezano et al. 2008, Cannavo et al. 2016), with downstream activation of RAC1 at least in endothelial cells. Here, activated MR increases GTP-bound RAC1 without increasing protein levels (Iwashima et al. 2008). RAC1 generates ROS by activating the NOX cytosolic subunit p47phox, which allows the assembly of other subunits into active NOX (Babior et al. 2002). Supplementing this process, MR activation also increases p47phox localisation to the cell membrane (Keidar et al. 2004, Miyata et al. 2005a, Nagata et al. 2006). However, there is a much slower increase in NOX activity over $6 \mathrm{~h}$ by aldosterone in endothelial cells suggesting that this process is distinct to that seen in VSMCs and cardiomyocytes (Iwashima et al. 2008). MR also signals via EGFR to increase NOX generation of ROS, and can synergise with angiotensin II to do so (Montezano et al. 2008). In cardiomyocytes, the MR-EGFR interaction utilises the PI3K/Akt cascade to activate NOX, which in turn triggers mitochondria to generate even more ROS in a feed-forward effect (Nolly et al. 2014). The MRAGTR1 interaction separately contributes by inducing mitochondrial localisation of GRK2 which promotes ROS generation (Cannavo et al. 2016).

Additionally, MR upregulates NOX by genomic means: increasing synthesis of NOX cytosolic subunits in renal mesangial cells, endothelial cells and heart (Miyata et al. 2005a, Nagata et al. 2006, Stas et al. 2007). MAPK signalling remains important for NOX2 synthesis, as knockout of

Published by Bioscientifica Ltd. 
apoptosis signal-regulating kinase 1 (ASK1), a MAPK kinase kinase, attenuates aldosterone-induced cardiac NOX2 upregulation, superoxide generation and cardiac fibrosis (Nakamura et al. 2009). AGTR1 signalling is required for MR-mediated $N c f 1$ transcription (the p47phox gene) in rat aorta, but not for other subunits (Hirono et al. 2007). This latter effect is in parallel to the AGTR1 synergy with $\mathrm{MR}$ in EGFR/PI3K signalling in cardiomyocytes discussed previously (Montezano et al. 2008).

Cellular redox status influences many of the cellular processes triggered by MR activation and even the method of MR activation itself (Fig. 1, sections B and C). For instance, ligand-free MR activation enabled in oxidative stress may partially explain the benefits to cardiac infarct healing with spironolactone treatment of adrenalectomised rats, despite the absence of endogenous ligands to activate the MR (Mihailidou et al. 2009). The generation of ROS is a necessary co-factor for certain MR signalling pathways; for example, antioxidant treatment attenuates the ability of aldosterone to transactivate EGFR (Huang et al. 2009) and IGF1R (Cascella et al. 2010). Also, some MR-mediated transcription could be redox sensitive including SGK1, SLC9A1 (encoding for NHE-1), and some pro-inflammatory and profibrotic genes (Callera et al. 2005, Pinto et al. 2008, Nakamura et al. 2009). The specific mechanisms of ROS contribution to MR function and maladaptive organ remodelling and damage will be described in the next section.

\section{Examples of coordinated MR transcriptional and rapid signalling effects in homeostasis and disease}

Although most of the cell signalling systems activated by MR and mineralocorticoids are ubiquitous, a uniform coordinated response is observed within specific tissues. While this has been best characterised in renal tubular epithelial cells, there is expanding knowledge of the mechanisms of MR effect in the cardiovascular system and immune cells. In this section, the interaction between aldosterone, MR, second messenger systems, receptor transactivation and gene transcription will be illustrated in the context of organ function or disease.

\section{Renal sodium handling}

The MR is expressed in epithelial cells, most importantly in the distal nephron (Doucet \& Katz 1981, Farman et al. 1982), but also in sweat glands (Kenouch et al. 1994), the gastrointestinal tract (Rafestin-Oblin et al. 1984) and mammary glands (Quirk et al. 1983), where it regulates cellular electrolyte handling. MR activation leads to both rapid and sustained homeostatic effects through a combination of second messenger signalling and early and later transcribed genes, which have been best characterised in the renal epithelial cell. This is illustrated in Fig. 2, and described in detail in the following sections.

MR regulation of target genes is the most potent determinant of its life-sustaining effects (Fig. 2, sections $B$ and C). MR-knockout mice suffer early demise due to dehydration and salt wasting despite compensatory elevation in the components of the RAAS (Berger et al. 1998). This fate is shared by mice homozygous for a non-synonymous substitution in the MR DBD, which abolishes its ability to bind to DNA and regulate primary gene transcription (Cole et al. 2015). Hence, MR regulation of target genes is critical for this function. Examples of the effect of MR target genes are well described in renal physiology. All distal nephron epithelial cells express the $\mathrm{ENaC}$, which is the major contributor to resorption of sodium in the distal nephron (Kellenberger \& Schild 2002). ENaC is a heterotrimeric protein comprised of $\alpha$-, $\beta$ - and $\gamma$-subunits, which undergo intracellular processing before export via vesicles to the apical membrane where it becomes active (Eladari et al. 2012). MR activation increases sodium influx via $\mathrm{ENaC}$, partially through direct transcription of the $\alpha$-subunit (Scnn1A) (Masilamani et al. 1999, Mick et al. 2001). MR activation also increases total protein levels of the $\mathrm{Na} / \mathrm{K}$-ATPase pump within $24 \mathrm{~h}$, which is responsible for exporting sodium out of the basolateral cell membrane to the interstitium (Alvarez de la Rosa et al. 2006).

MR also increases the expression of genes that regulate post-translational modifications of the electrolyte handling machinery, providing a more rapid response than direct synthesis of channels or transporters (Fig. 2, section B). SGK1 is one such rapidly transcribed gene, which increases activity of ENaC (Chen et al. 1999). It also increases thiazide-sensitive sodium chloride cotransporter (NCC) activity (Faresse et al. 2012, Ko et al. 2013), which is a lesser contributor to renal sodium resorption (Gamba et al. 1994). The early effects of SGK1 are largely to preserve the active surface expression of ENaC and NCC. SGK1 phosphorylates the ubiquitin protein ligase Nedd42, preventing it from tagging ENaC or NCC for destruction (Snyder et al. 2002, Arroyo et al. 2011). SGK1 also directly interacts with the SCNN1A to increase the proportion of active open ENaC channels (Diakov \& Korbmacher 2004), and promotes ENaC transcription (Zhang et al. 2007). With similar enhancing effects on NCC (Rozansky et al. 2009,

Published by Bioscientifica Ltd. 


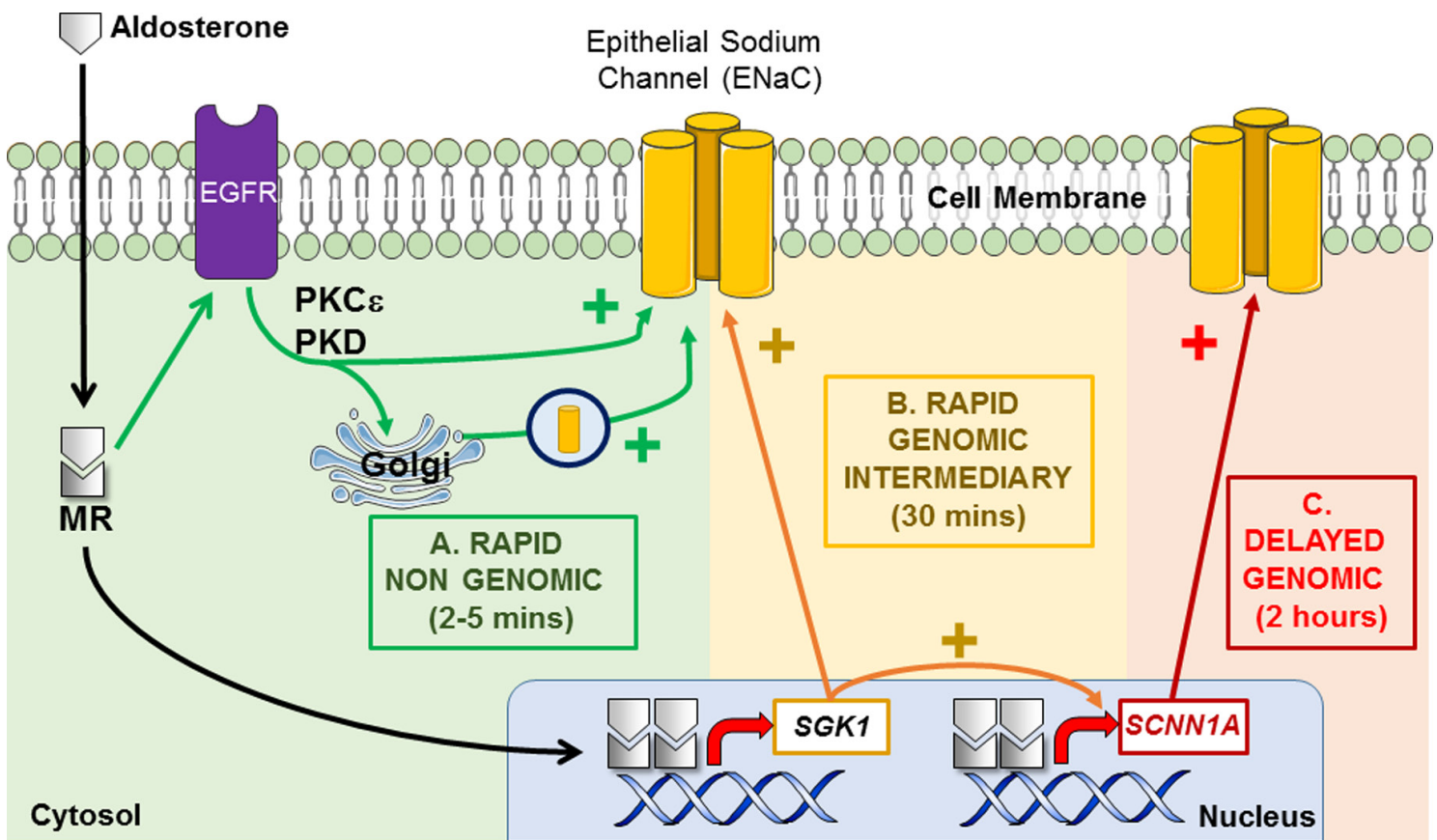

\section{Figure 2}

Time course of MR effects on epithelial sodium channel (ENaC) activity in renal epithelial cells. Once activated by aldosterone, the MR triggers rapid signalling pathways, and increases transcription of intermediary genes (such as SGK1, CNKSR3 and GILZ) which enhance ENaC activity and prevent degradation, as well as direct transcription of SCNN1A which codes for the ENaC channel $\alpha$-subunit. In combination, the MR can provide a rapid and sustained $\mathrm{ENaC}$ mediated sodium resorption in response to hypovolaemia.

Ko et al. 2013) and $\mathrm{Na} / \mathrm{K}$-ATPase expression and activity (Zecevic et al. 2004, Alvarez de la Rosa et al. 2006), SGK1 is crucial in early and delayed mechanisms of electrolyte transport. Other MR target genes act synergistically with SGK1 to prevent ENaC and NCC destruction. Examples include ubiquitin-specific protease 2-45 (Oberfeld et al. 2011), CNKSR3 (Soundararajan et al. 2012) and GILZ1 (Soundararajan et al. 2010).

Non-canonical rapid MR-mediated effects on ENaC increase its surface expression and activity (Fig. 2, section A). MR signalling via IGF1R activates PI3K (Blazer-Yost et al. 1999), with products of PI3K directly interacting with $\mathrm{ENaC}$ to increase the probability of open channels (Pochynyuk et al. 2007). This generates a rapid but transient effect for $1 \mathrm{~h}$, after which onset of genomic mechanisms (such as via SGK1) contribute to maintenance of ENaC activity (Holzman et al. 2007). Once SGK1 is upregulated, PI3K also promotes SGK1 phosphorylation (Wang et al. 2001, Collins et al. 2003). MR transactivation of the EGFR, with downstream activation of PKC and PKD1, mediates aldosterone effects on $\mathrm{ENaC}$ subunit trafficking and membrane integration. $\mathrm{PKC} \varepsilon$ is activated by aldosterone within $2 \mathrm{~min}$, forming PKC $\varepsilon-P K D 1$ complexes and activating PKD1 within 5 min (McEneaney et al. 2007, 2008). Similarly, intracellular trafficking of ENaC subunits is enhanced within 2 min and $\mathrm{ENaC}$ subunit translocation from cytoplasm to cell membrane within $30 \mathrm{~min}$ (McEneaney et al. 2008, Dooley et al. 2013). ENaC subunits are initially packaged in the Golgi apparatus, emerging from the adjacent transgolgi network in endosomes. Eventually these are directed towards, and insert into, the apical cellular membrane (Butterworth 2010). The MR-dependent increased activity of ENaC induced by aldosterone after $2-4 \mathrm{~h}$ is correlated with this redistribution, which cannot occur without PKD1 (McEneaney et al. 2008, 2010b, Dooley et al. 2013).

Second messenger systems activated by MR do not act in isolation, with components of some pathways capable of activating those of another. For example, K-RAS upregulates $\mathrm{ENaC}$ activity in a PI3K-dependent manner rather than via RAF-MEK-ERK1/2 (Staruschenko et al. 2004), which in fact is a negative regulator of ENaC (Grossmann et al. 2004). Occasionally, interactions between downstream second messengers can result in opposing cellular effects. For example, aldosterone induces PKD1 to rapidly form complexes with phosphatidylinositol 4-kinase IIIb (PI4KIIIb) in the trans-golgi network, which promotes export of ENaC subunits, and enhances the direct PKD1 effect on ENaC transport (Hausser et al. 2005, Dooley et al. 2013). However, PKD1 also prolongs MR-induced ERK1/2

Published by Bioscientifica Ltd 
activation (McEneaney et al. 2010a), which increases degradation of $\mathrm{ENaC}$ via PKC, to mitigate the effect of increased ENaC expression (Booth \& Stockand 2003).

\section{Vasomotor and endothelial function}

Vascular endothelial cells and VSMCs express the MR (Lombes et al. 1992), with MR signalling in these tissues contributing to regulation of vasomotor tone. However, the literature varies on if, and under what context, mineralocorticoids exert a constricting or relaxing effect, and whether that action is direct or via augmentation of responses to other vasoactive stimuli. A summary of MR signalling in vascular function is presented in Fig. 3.

Endothelial MR influences NO levels, which impacts on vascular tone (Fig. 3, top section). NO is generated by eNOS, which diffuses into adjacent VSMCs, and triggers generation of cyclic guanosine monophosphate (cGMP) which ultimately results in relaxation (Förstermann \& Münzel 2006). In bovine aortic endothelial cells, MR rapidly signals via PI3K/Akt to increase eNOS production of NO within 2 minutes (Liu et al. 2003, Mutoh et al. 2008). However, MR activation reduces eNOS activity in HUVECs (Hashikabe et al. 2006). Rapid induction of RhoA kinase activity by MR maximally reduces eNOS activity within $15 \mathrm{~min}$ by inhibition of Akt (Kirsch et al. 2013), while prolonged MR activation (16h) also inhibits eNOS activity by increasing protein phosphatase $2 \mathrm{~A}$ activity, which dephosphorylates eNOS (Nagata et al. 2006). As MR acts through different pathways with opposing outcomes, context is important in determining its effect on eNOS.

Vascular endothelial MR genomic effects increase oxidative stress. The NOX subunit p47phox has increased expression and membrane localisation in response to MR activation, with ROS generation after $2 \mathrm{~h}$ (Nagata et al. 2006). Additionally, aortic expression of cyclooxygenase (COX)-2 is increased in aldosterone-treated rats (BlancoRivero et al. 2005, Eatman et al. 2011). COX-2 generates vasoactive prostanoids and ROS (Félétou et al. 2011), which impairs vasodilatory (Blanco-Rivero et al. 2005) and

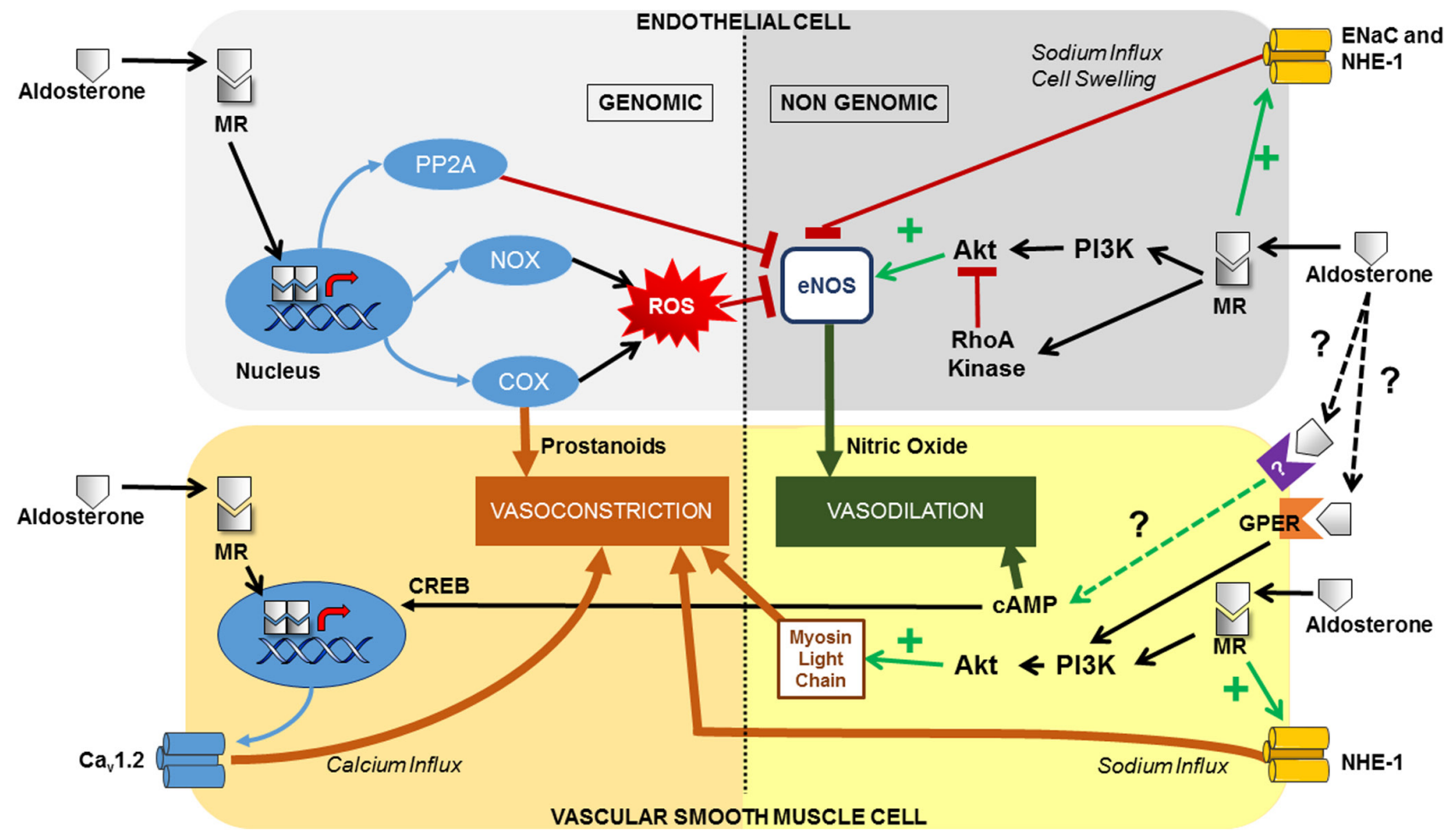

Figure 3

Mineralocorticoid mediated genomic (left) and non-genomic (right) events in the control of vascular function. In both endothelial (top section) and vascular smooth muscle cells (VSMCs), the PI3K pathway is an important second messenger system through which MR activates endothelial nitric oxide synthase (eNOS) and VSMC contractile elements such as myosin light chain (MLC). In VSMC, the presence of GPER enhances the effect through unknown mechanisms. Rapid effects on the ENaC sodium channel and sodium/hydrogen exchanger (NHE-1) are pro-constrictive. In VSMC, rapid increases to CAMP leads to upregulation of the CREB transcription factor, linking rapid signalling and genomic transcription. Genomic effects in endothelium includes increased synthesis of protein phosphatase 2A (PP2A) which deactivates eNOS, and NADPH oxidase (NOX) and cyclooxygenase (COX) which generate reactive oxygen species (ROS) impairing eNOS function. In VSMC, the MR can upregulate $\mathrm{Ca}_{\mathrm{v}} 1.2$, an L-type voltage dependent calcium channel. The balance between different MR effects and other in vivo mediators determines overall vasomotor tone. 
enhances vasoconstrictive responses (Eatman et al. 2011). The effect of aldosterone on COX-2 expression is not uniform; it induces upregulation of COX-2 in the aorta and renal arteries, whereas it induces downregulation in the femoral artery (Eatman et al. 2011). These studies did not specifically investigate if these aldosterone effects were MR mediated, although in two different studies, eplerenone mitigated both angiotensin II (Rocha et al. 2002a) and aldosterone (Rocha et al. 2002b) induced cardiac COX-2 upregulation in rats. MR activation reduces glucose-6-phosphate dehydrogenase (G6PD) expression, which worsens oxidative stress and impairs both NO generation and NO-dependent vasodilation (Leopold et al. 2007). This environment of MR-mediated oxidative stress can compound adverse events such as the inactivating oxidative modification of endothelin-B receptor, which prevents its stimulation of eNOS (Maron et al. 2012). It also contributes to depletion of tetrahydro-L-biopterin (BH4), a potent reducing agent and co-factor for $\mathrm{NO}$ generation by eNOS. Depletion of BH4 uncouples eNOS, causing production of more ROS instead of NO, and is a contributing mechanism for MR-mediated reduction in endothelial NO production (Förstermann \& Münzel 2006, Nagata et al. 2006, Chen et al. 2016). In PA, BH4 depletion and oxidative stress correlates with impaired endothelial healing in response to injury (Chen et al. 2016).

Aldosterone and MR also exert NO-independent effects on vasomotor function. Endothelial cell volume and tension are increased by aldosterone with deleterious effect. Aldosterone-induced rapid activation of NHE-1 (Schneider et al. 1997) and/or ENaC (Oberleithner et al. 2003) contributes to swelling, which is transient. Later, MR-mediated synthesis of cytosol-crowding macromolecules occurs with prolonged aldosterone exposure, which stiffens the cell and renders it susceptible to shear stress (Oberleithner et al. 2006). MR antagonism blocks all but the very early $(<1 \mathrm{~min})$ changes to cell volume and stiffness (Oberleithner et al. 2006).

Activation of the endothelial MR can both increase and reduce vascular reactivity and tone suggesting a complex regulatory framework, but there is also heterogeneity of experimental conditions in the literature. These differences include anatomical site, steroid dose and duration of exposure, and environmental context. For example, endothelial cell-specific MR deletion improved NO-dependent vasodilatory responsiveness after 2 weeks of angiotensin II exposure in mesenteric but not coronary arterioles (Mueller et al. 2015). Also, in bovine aortic endothelial cells, eNOS activity is maximally activated by picomolar to nanomolar concentrations of aldosterone, with diminished effect at higher concentrations (Liu et al. 2003, Leopold et al. 2007). However, in human coronary microarteries, maximal eNOS activation required higher than micromolar concentrations (Batenburg et al. 2012). Furthermore, while early rapid MR effects in afferent renal arterioles promote vasodilation, delayed-onset genomic effects can be vasoconstrictive (Uhrenholt et al. 2003). The heterogeneity extends to signalling through other receptors. Aldosterone activation of GPER results in an endothelium-dependent vasodilatory tendency in rat aorta (Gros et al. 2013), but potentiates angiotensinII-induced vasoconstriction in human coronary arteries in an MAPK- and NO-independent mechanism (Batenburg et al. 2012). As AGTR1a signalling is important for aldosterone-mediated endothelial dysfunction (Briet et al. 2016), this discordance may reflect a specific AGTR1 effect in the latter study. In vitro cell culture and ex vivo isolated vessel experimental systems cannot replicate the complex in vivo milieu of changeable and interacting autonomic, endocrine, paracrine and stress related inputs, which together generate more unity of purpose than seen across individual experiments.

In the VSMC, MR signalling is important for maintaining basal tone and vascular contractile responses (Fig. 3, bottom section). If MR is deleted, cGMP- and calcium-dependent signalling is impaired with reduction in baseline activation of the contractile regulators myosin light chain kinase (MLCK) and myosin light chain (MLC) 2 (Tarjus et al. 2015a). The phosphorylation of MLC by MLCK is a necessary step in enabling actin-myosin coupling (Goulopoulou \& Webb 2014) and occurs within $15 \mathrm{~min}$ of MR activation via PI3K signalling (Gros et al. 2011a). The basal expression of genes coding for contractile elements, ion channels or signalling systems is unaffected by MR deletion in VSMC (Tarjus et al. 2015a). However, MR does regulate $\mathrm{Ca}_{\mathrm{v}} 1.2$ gene expression in mesenteric artery VSMC, an L-type calcium channel which increases vasomotor tone when active (McCurley et al. 2012). Aldosterone can also act in an MR-independent mechanism to increase VSMC cAMP levels within $1 \mathrm{~min}$, which activates the transcription factor CREB within $10 \mathrm{~min}$, linking rapid signalling with genomic transcription (Christ et al. 1999).

Sodium handling in VSMCs is under mineralocorticoid control. NHE-1 activity and sodium influx are increased by aldosterone in a biphasic manner: a rapid MR-independent mechanism and a prolonged MR-dependent response (Miyata et al. 2005b, Carreno et al. 2015). The resultant rise in intracellular sodium is exacerbated by an early transient MR-induced,

Published by Bioscientifica Ltd 
PKC-dependent reduction in VSMC Na/K-ATPase surface activity and expression (Alzamora et al. 2003). However, with sustained MR activation and sodium influx, there is increased $\mathrm{Na} / \mathrm{K}-\mathrm{ATP}$ ase subunit transcription (Muto et al. 1996). These changes affect cellular membrane potentials and calcium handling, with potential consequences on VSMC function (MR-mediated NHE-1 activity contributes to vasoconstrictive responses in the aorta) (Carreno et al. 2015).

Functionally, VSMC MR generally promotes a contractile response, augmenting the constrictor effect of thromboxane-A2 and angiotensin II in aged animals (Gros et al. 2011a, McCurley et al. 2012). VSMC MR has a role in hypertension, with VSMC MR knockout mice having lower basal blood pressures (Galmiche et al. 2014) and protection against age-related increases to systolic blood pressure (McCurley et al. 2012). However, MR also is important for NO-mediated relaxation of VSMC, and increases cAMP that has a vasodilatory effect, which may be autoregulatory in the presence of functional endothelium (Christ et al. 1999, Tarjus et al. 2015a).

\section{The cardiac action potential, excitation-contraction coupling and electrical remodelling}

The identification of MR expression in human cardiomyocytes indicates that MR exerts direct effects on the heart (Bonvalet et al. 1995, Lombes et al. 1995). Cardiomyocyte contraction is critically dependent upon intracellular calcium, which binds to troponin-C, unleashing a cascade of events that eventually facilitate actin and myosin filament movement and sarcomere contraction. Calcium influx and release from the sarcoplasmic reticulum is triggered by electrical depolarisation of the vesicle membrane. Atrial and ventricular cardiomyocytes are prone to rapid depolarisation, with their electrical status determined by the actions of sodium, calcium and potassium channels. Voltage-gated calcium channels are important for coupling depolarisation to contraction, by facilitating calcium influx into the cell and triggering the release of calcium from the sarcoplasmic reticulum (Lipscombe 2002). MR activity can thus modulate cardiomyocyte electrolyte handling, the action potential and cardiac contractility.

Cardiomyocytes express both low-voltage-activated T-type channels which exhibit rapid activation and slow deactivation, and L-type dihydropyridine channels which activate more slowly but deactivate more rapidly than T-type channels (Lipscombe 2002). Both are also important for pacemaker activity and propagation of action potentials. MR activation increases calcium current through both L-type and T-type calcium channels (Lalevee et al. 2005, Boixel et al. 2006). The calcium status of cardiomyocytes is strongly linked to transmembrane sodium concentrations (Bogeholz et al. 2012, Aronsen et al. 2013). Aldosterone raises intracellular sodium levels by rapidly promoting sodium influx through the NHE-1 (Korichneva et al. 1995, Matsui et al. 2007) within 10 min via MR transactivation of EGFR (De Giusti et al. 2011), the electrogenic sodium/bicarbonate cotransporter (SLC4A4) via GPER and PI3K/Akt (De Giusti et al. 2015, Orlowski et al. 2016), and the Na-K-2Cl cotransporter (SLC12A) via a PKCe-dependent pathway (Mihailidou et al. 1998, 2004). This PKCE pathway also mediates a reduction in $\mathrm{Na} / \mathrm{K}$-ATPase activity, inhibiting sodium export (Mihailidou et al. 2000, 2004). While SLC12A activity continues with prolonged MR signalling, the $\mathrm{Na} / \mathrm{K}$-ATPase inhibition is only transient (Mihailidou et al. 2004).

As a regulator of intracellular $\mathrm{pH}$ and cell volume through the exchange of sodium for hydrogen, NHE-1-dependent cellular alkalinisation can increase myofilament responsiveness to calcium (Mattiazzi 1997) and may explain aldosterone's rapid inotropic effect on cardiomyocytes (Barbato et al. 2002, 2004). NHE-1 is also important in generating a stretch-induced secondary slow force contractile reaction that occurs after the initial Frank-Starling response. It is postulated that an angiotensin-II-mediated local generation of aldosterone acts via EGFR, with downstream ROS generation and ERK1/2 phosphorylation activating NHE-1 to trigger contraction. MR knockdown with hairpin interfering RNA blocks the slow force response, with reduced ERK1/2 phosphorylation and NHE-1 activity (Diaz et al. 2014). Although this hypothesis is controversial due to difficulty in identifying aldosterone synthase in the heart (Ye et al. 2005), increased aldosterone synthase gene expression in heart failure patients (Yoshimura et al. 2002) and the persistence of aldosterone in the hearts of adrenalectomised rats (Gomez-Sanchez et al. 2004) suggest some cardiac capacity for aldosterone generation in response to major disturbances to normal function.

There is the possibility that MR can mediate electrical dysfunction. Cardiac-specific overexpression of MR in mice leads to an increase in action potential duration and ventricular arrhythmia due to aberrant release of calcium from the sarcoplasmic reticulum (Ouvrard-Pascaud et al. 2005, Gomez et al. 2009). In humans, PA patients are at higher risk of atrial fibrillation (AF) compared to age and blood pressure matched controls (Milliez et al. 2005,

Published by Bioscientifica Ltd 
Catena et al. 2008, Savard et al. 2013). Electrical remodelling, such as upregulation of calcium channels and downregulation of potassium channels, precedes MR-mediated structural remodelling suggesting a dual mechanism for arrhythmia pathogenesis (Lalevee et al. 2005, Ouvrard-Pascaud et al. 2005).

\section{Cardiovascular inflammation, fibrosis and repair}

Chronic excessive MR activation is uniformly associated with adverse cardiovascular outcomes, as seen in PA. The persistent excessive secretion of aldosterone is associated with hypertension and end organ disease, including cardiac left ventricular hypertrophy (Rossi et al. 1996, 2013) and renal impairment (Sechi et al. 2006). Patients with PA have increased risk of significant cardiovascular disease (CVD) events, such as stroke and myocardial infarction (MI), beyond that attributable solely to hypertension (Milliez et al. 2005, Mulatero et al. 2013). Treatment reduces the risk of significant CVD events to that experienced by treated primary ('essential') hypertension patients (Catena et al. 2008).

Curiously, there is clinical evidence of benefit when MR antagonists are used in disease states unrelated to mineralocorticoid excess, such as heart failure after myocardial infarction (Pitt et al. 2003). In animal models of cardiac damage from pressure overload (Lother et al. 2011, Li et al. 2014), oxidative stress (Usher et al. 2010, Bienvenu et al. 2012, Coelho-Filho et al. 2014), valvular incompetence (Zendaoui et al. 2012) and MI (Delyani et al. 2001, Enomoto et al. 2005, Takeda et al. 2007). Cardiac remodelling with impairment to systolic and/or diastolic function is attenuated through either cell-specific MR knockdown/deletion, or use of MR antagonists such as spironolactone and eplerenone. These benefits may be due to inhibition of glucocorticoid rather than mineralocorticoid activation of MR. However, the presence of endogenous ligands may not be required for MR-mediated adverse outcomes, with ongoing protection from spironolactone in an animal model of MI after adrenalectomy (Mihailidou et al. 2009) and the potential for RAC1-induced ligand-free MR activation (Nagase et al. 2012). This suggests that MR signalling influences cardiovascular recovery from injury through multiple mechanisms, and the contribution of MR to pathology extends more broadly than hyperaldosteronism or hypertension.

Persistent MR overactivation is associated with perivascular and cardiac inflammation within 14 days of constant mineralocorticoid exposure (Rocha et al. 2002b, Usher et al. 2010, Rickard et al. 2012). This arises after upregulation of factors that enhance leucocyte recruitment, adhesion and infiltration. In endothelial cells, this includes intercellular adhesion molecule (ICAM1), CCR5 and P-selectin (Caprio et al. 2008, Jeong et al. 2009, Rickard et al. 2014). Also, MR induces placental growth factor production in VSMC, which recruits monocytes via FLT1, a vascular endothelial growth factor (VEGF) receptor (McGraw et al. 2013). MR can indirectly regulate transcription of genes involved in recruitment and adhesion, with ICAM1 and vascular cell adhesion molecule-1 (VCAM1) protein expression upregulation via PDGFR and c-Src activation (Callera et al. 2011a), and osteopontin via ERK and p38 MAPK (Fu et al. 2012). Once recruited, MR signalling is important for activating and influencing the behaviour of inflammatory cells. Myeloid cells increase the generation of pro-inflammatory cytokines such as TNF- $\alpha$, IL-1b and IL-6 in response to aldosterone (Usher et al. 2010). Many of these are under the regulation of $\mathrm{NF}-\kappa \mathrm{B}$, whose activity is enhanced by SGK1 (Zhang et al. 2005, Leroy et al. 2009, Ding et al. 2012). Conversely, macrophages derived from peripheral blood monocytes of healthy human volunteers developed an anti-inflammatory, pro-healing genetic transcription profile in response to MR antagonist treatment. This profile is similar to that induced by IL-4, which is known to polarise macrophages to an anti-inflammatory phenotype (Labuzek et al. 2013).

Matrix metalloproteinases (MMPs) degrade collagen and cleave precursors of pro-inflammatory cytokines into active forms (Schonbeck et al. 1998). MR activation upregulates MMP production utilising various second messenger pathways, enhancing inflammatory cell infiltration. In neutrophils, increased transcription of MMP9 and pro-angiogenic VEGFA by MR requires intact PI3K, p38 MAPK and ERK signalling (Walczak et al. 2011, Gilet et al. 2015). In myeloid cells, such as macrophages, MMP12 production requires intact MR signalling via JNK/AP-1 and ERK cascades (Shen et al. 2016). In cardiomyocytes, PKC and the generation of ROS by NOX are prerequisites for MR-mediated ERK activation and MMP9 generation (Rude et al. 2005). The MR-induced ROS oxidises calcium/calmodulin-dependent protein kinase II (CAMK2), which drives Mmp9 transcription by myocyte enhancer factor 2 (MEF2) (He et al. 2011).

A number of MR-regulated genes are mitogenic, pro-hypertrophic and profibrotic and, similar to chemoattractant factors, are subject to indirect $\mathrm{MR}$

Published by Bioscientifica Ltd. 
regulation using second messenger systems. For example, MR acts through ERK signalling to induce cardiac fibroblast proliferation (Stockand \& Meszaros 2003) and cardiomyocyte transcription of hypertrophyassociated proteins such as $\alpha$ - and $\beta$-myosin heavy chain (Okoshi et al. 2004). Additionally, MR signalling via p38 MAPK promotes cardiomyocyte production of connective tissue growth factor (CTGF), which is a profibrotic stimulus (Lee et al. 2004). Transactivation of other receptor systems is involved in MR-mediated remodelling. AGTR1 transactivation is required for the upregulation of fibrotic and hypertrophic genes such as transforming growth factor-beta (TGF- $\beta$ ), Col1a, Col3a and Acta2 (which encodes $\alpha$-smooth muscle actin) in cardiomyocytes via ERK and JNK (Tsai et al. 2013), while the pro-hypertrophic MEF2 requires AGTR1 signalling via the G-protein coupled receptor kinase (GRK) 5 (Cannavo et al. 2016). In cardiac fibroblasts, aldosterone acts via an unknown membrane G-protein coupled receptor (and not MR) to transactivate IGF1R via c-Src, with downstream PI3K/Akt signalling leading to elastin production (Bunda et al. 2009). EGFR transactivation by cardiac MR increases NHE-1 activity (Fujisawa et al. 2003, Young \& Funder 2003, De Giusti et al. 2011) with resultant sodium accumulation promoting calcium influx and activation of MAPK (p38, ERK), Akt, calcineurin and CAMK2. This facilitates the generation of pro-hypertrophic factors (Darmellah et al. 2007, Nakamura et al. 2008). EGFR transactivation may be profibrotic, as it is mitogenic in a renal fibroblast cell line via JNK, ERK and PI3K/Akt cascades (Huang et al. 2012). However, in vivo impact on fibrosis may be limited, with impaired EGFR function not protecting mice against mineralocorticoid-induced cardiac remodelling (Messaoudi et al. 2012). Several profibrotic genes are directly regulated by $\mathrm{MR}$ as a transcription factor. As in the kidney, MR increases SGK1 transcription in the heart (Martin-Fernandez et al. 2011). SGK1 upregulates the profibrotic CTGF (Vallon et al. 2006, Terada et al. 2012), and the importance of SGK1 in the pathogenesis of MR-mediated cardiac fibrosis has been established in a knockout mouse model (Vallon et al. 2006). Neutrophil gelatinase-associated lipocalin (Lcn2) is a directly MR-regulated gene in cardiomyocytes (Latouche et al. 2012). LCN2 is a stimulus for fibroblasts to deposit type 1 collagen and plays a pathological role in MR-mediated coronary perivascular fibrosis (Tarjus et al. 2015b).

Oxidative stress is a key facilitator of adverse remodelling and inflammatory effects of the MR including rapid effects on vascular function and the increased transcription of culprit genes. As MR activation simultaneously promotes production of ROS, particularly through NOX2, a self-sustaining interaction could exacerbate and potentiate inflammation and fibrosis. MR is important for the transcription of NOX and its p22phox subunit (Fiore et al. 2009). In the heart, this appears to be driven by infiltrating macrophages, as prevention of their recruitment reduces NOX upregulation and cardiac fibrosis (Rickard et al. 2012, Shen et al. 2014). Aldosterone acts via MAPK to increase NOX2, CCL2 and TGF- $\beta 1$ expression and to cause cardiac fibrosis (Nakamura et al. 2009). NOX-generated ROS also contributes to vascular remodelling. MR-induced IGF1R expression, activation and downstream signalling (via MAPK and PI3K/Akt) with subsequent VSMC cell proliferation and migration are ROS dependent (Cascella et al. 2010). Similarly, the reparative function of endothelial progenitor cells from PA patients is impaired by eNOS uncoupling related to increased NOX production of ROS (Chen et al. 2016). Therefore, redox status determines the outcome of several MR-mediated pathological processes.

\section{Conclusions}

So far, the uncovered mechanisms of action of mineralocorticoids and the MR paint a picture of a sophisticated multifunctional system. Harnessing cellular second messenger systems while genomic transcription events are given sufficient time to increase and sustain its defence against hypovolaemia, MR activation in the kidney and vessels shows itself to be an agile and powerful preserver of homeostasis. Yet, MR activation and triggering of the same genes and signalling pathways elsewhere and under different circumstances can lead to recruitment of inflammatory cells and fibrosis or maladaptive repair in response to injury. There is an increasing body of work regarding the contribution of various MR expressing cell types to tissue inflammation, fibrosis, maladaptation and hypertension, but there is a concurrent need to map the gene targets and intracellular signalling pathways underlying these outcomes. Eventually, this could lead to novel therapeutic options such as targeting transactivated receptors and superoxide generation in combination with MR antagonism. There is also scope for development of new agents that preferentially obstruct pathological signalling whilst preserving the essential electrolyte regulatory effects of MR.

There are many unresolved issues in mineralocorticoid and MR signalling. It is likely that http://jme.endocrinology-journals.org DOI: 10.1530/JME-15-0318
() 2017 Society for Endocrinology Printed in Great Britain
Published by Bioscientifica Ltd 
additional mechanisms protect the MR against nonspecific activation by its several high-affinity ligands or context-dependent ligand-free activation. Similarly, there is more to discover about the membrane receptors through which mineralocorticoids can induce effects without binding to its classical MR, although there is increasing evidence that GPER is involved. The mechanism of MR interaction with GPER itself is incomplete, and other candidate receptors may exist including the elusive membrane bound MR. However, current research methods in this area largely rely on in vitro and ex vivo experiments in isolated systems, which cannot account for the numerous contributing inputs in in vivo systems. As the body of research expands, there is a risk of confusion from inconsistencies and variations in mechanisms and functional outcomes between studies. Instead, we hope that clearer patterns will emerge, leading us closer to the intelligent design behind the multifunctional MR.

\section{Declaration of interest}

The authors declare that there is no conflict of interest that could be perceived as prejudicing the impartiality of this review.

\section{Funding}

G O is supported by the Australian Government's Australian Postgraduate Award scholarship. The Hudson Institute is supported by the Victorian Government's Operational Infrastructure Support Program.

\section{Acknowledgements}

The authors would like to thank Dr Jun Yang for critical appraisal and editing of the manuscript.

\section{References}

Abbas A, Grant PJ \& Kearney MT 2008 Role of IGF-1 in glucose regulation and cardiovascular disease. Expert Review of Cardiovascular Therapy 6 1135-1149. (doi:10.1586/14779072.6.8.1135)

Ackermann D, Gresko N, Carrel M, Loffing-Cueni D, Habermehl D, Gomez-Sanchez C, Rossier BC \& Loffing J 2010 In vivo nuclear translocation of mineralocorticoid and glucocorticoid receptors in rat kidney: differential effect of corticosteroids along the distal tubule. American Journal of Physiology: Renal Physiology 299 F1473-F1485. (doi:10.1152/ajprenal.00437.2010)

Alvarez de la Rosa D, Gimenez I, Forbush B \& Canessa CM 2006 SGK1 activates Na+-K+-ATPase in amphibian renal epithelial cells. American Journal of Physiology: Cell Physiology 290 C492-C498. (doi:10.1152/ ajpcell.00556.2004)

Alzamora R, Marusic ET, Gonzalez M \& Michea L 2003 Nongenomic effect of aldosterone on $\mathrm{Na}+, \mathrm{K}+$-adenosine triphosphatase in arterial vessels. Endocrinology 144 1266-1272. (doi:10.1210/en.2002-220950)

Aronsen JM, Swift F \& Sejersted OM 2013 Cardiac sodium transport and excitation-contraction coupling. Journal of Molecular and Cellular Cardiology 61 11-19. (doi:10.1016/j.yjmcc.2013.06.003)
Arriza JL, Weinberger C, Cerelli G, Glaser TM, Handelin BL, Housman DE \& Evans RM 1987 Cloning of human mineralocorticoid receptor complementary DNA: structural and functional kinship with the glucocorticoid receptor. Science $\mathbf{2 3 7}$ 268-275. (doi:10.1126/science.3037703)

Arroyo JP, Lagnaz D, Ronzaud C, Vazquez N, Ko BS, Moddes L, RuffieuxDaidie D, Hausel P, Koesters R, Yang B, et al. 2011 Nedd4-2 modulates renal Na+-Cl- cotransporter via the aldosterone-SGK1Nedd4-2 pathway. Journal of the American Society of Nephrology 22 1707-1719. (doi:10.1681/ASN.2011020132)

Ashton AW, Le TY, Gomez-Sanchez CE, Morel-Kopp MC, McWhinney B, Hudson A \& Mihailidou AS 2015 Role of nongenomic signaling pathways activated by aldosterone during cardiac reperfusion injury. Molecular Endocrinology 29 1144-1155. (doi:10.1210/ME.2014-1410)

Ayuzawa N, Nagase M, Ueda K, Nishimoto M, Kawarazaki W, Marumo T, Aiba A, Sakurai T, Shindo T \& Fujita T 2015 Rac1-mediated activation of mineralocorticoid receptor in pressure overload-induced cardiac injury. Hypertension 67 99-106. (doi:10.1161/ HYPERTENSIONAHA.115.06054)

Babior BM, Lambeth JD \& Nauseef W 2002 The neutrophil NADPH oxidase. Archives of Biochemistry and Biophysics 397 342-344 (doi:10.1006/abbi.2001.2642)

Baker ME, Funder JW \& Kattoula SR 2013 Evolution of hormone selectivity in glucocorticoid and mineralocorticoid receptors. Journal of Steroid Biochemistry and Molecular Biology 137 57-70. (doi:10.1016/j.jsbmb.2013.07.009)

Barbato JC, Mulrow PJ, Shapiro JI \& Franco-Saenz R 2002 Rapid effects of aldosterone and spironolactone in the isolated working rat heart. Hypertension 40 130-135. (doi:10.1161/01.HYP.0000025879.29822.24)

Barbato JC, Rashid S, Mulrow PJ, Shapiro JI \& Franco-Saenz R 2004 Mechanisms for aldosterone and spironolactone-induced positive inotropic actions in the rat heart. Hypertension 44 751-757. (doi:10.1161/01.HYP.0000144466.11568.7e)

Barton M \& Meyer MR 2015 Nicolaus Copernicus and the rapid vascular responses to aldosterone. Trends in Endocrinology and Metabolism 26 396-398. (doi:10.1016/j.tem.2015.05.005)

Batenburg WW, Jansen PM, van den Bogaerdt AJ \& AH JD 2012 Angiotensin II-aldosterone interaction in human coronary microarteries involves GPR30, EGFR, and endothelial NO synthase. Cardiovascular Research 94 136-143. (doi:10.1093/cvr/cvs016)

Bedard K \& Krause KH 2007 The NOX family of ROS-generating NADPH oxidases: physiology and pathophysiology. Physiological Reviews $\mathbf{8 7}$ 245-313. (doi:10.1152/physrev.00044.2005)

Berger S, Bleich M, Schmid W, Cole TJ, Peters J, Watanabe H, Kriz W, Warth R, Greger R \& Schutz G 1998 Mineralocorticoid receptor knockout mice: pathophysiology of $\mathrm{Na}+$ metabolism. PNAS $\mathbf{9 5}$ 9424-9429. (doi:10.1073/pnas.95.16.9424)

Beuschlein F 2013 Regulation of aldosterone secretion: from physiology to disease. European Journal of Endocrinology 168 R85-R93. (doi:10.1530/EJE-13-0263)

Bienvenu LA, Morgan J, Rickard AJ, Tesch GH, Cranston GA, Fletcher EK, Delbridge LM \& Young MJ 2012 Macrophage mineralocorticoid receptor signaling plays a key role in aldosteroneindependent cardiac fibrosis. Endocrinology 153 3416-3425. (doi:10.1210/en.2011-2098)

Blanco-Rivero J, Cachofeiro V, Lahera V, Aras-Lopez R, Marquez-Rodas I, Salaices M, Xavier FE, Ferrer M \& Balfagon G 2005 Participation of prostacyclin in endothelial dysfunction induced by aldosterone in normotensive and hypertensive rats. Hypertension 46 107-112. (doi:10.1161/01.HYP.0000171479.36880.17)

Blazer-Yost BL, Paunescu TG, Helman SI, Lee KD \& Vlahos CJ 1999 Phosphoinositide 3-kinase is required for aldosterone-regulated sodium reabsorption. American Journal of Physiology 277 C531-C536.

Bogeholz N, Muszynski A \& Pott C 2012 The physiology of cardiac calcium handling. Wiener Medizinische Wochensschrift 162 278-282. (doi:10.1007/s10354-012-0102-3) 
Boixel C, Gavillet B, Rougier JS \& Abriel H 2006 Aldosterone increases voltage-gated sodium current in ventricular myocytes. American Journal of Physiology: Heart and Circulatory Physiology 290 H2257-H2266. (doi:10.1152/ajpheart.01060.2005)

Bonvalet JP, Alfaidy N, Farman N \& Lombes M 1995 Aldosterone: intracellular receptors in human heart. European Heart Journal 16 (Supplement N) 92-97. (doi:10.1093/eurheartj/16.suppl_N.92)

Booth RE \& Stockand JD 2003 Targeted degradation of ENaC in response to PKC activation of the ERK1/2 cascade. American Journal of Physiology: Renal Physiology 284 F938-F947. (doi:10.1152/ ajprenal.00373.2002)

Brem AS, Bina RB, King TC \& Morris DJ 1998 Localization of 2 11beta-OH steroid dehydrogenase isoforms in aortic endothelial cells. Hypertension 31 459-462. (doi:10.1161/01.HYP.31.1.459)

Briet M, Barhoumi T, Mian MO, Coelho SC, Ouerd S, Rautureau Y, Coffman TM, Paradis P \& Schiffrin EL 2016 Aldosterone-induced vascular remodeling and endothelial dysfunction require functional angiotensin type 1a receptors. Hypertension 67 897-905. (doi:10.1161/HYPERTENSIONAHA.115.07074)

Bunda S, Liu P, Wang Y, Liu K \& Hinek A 2007 Aldosterone induces elastin production in cardiac fibroblasts through activation of insulin-like growth factor-I receptors in a mineralocorticoid receptorindependent manner. American Journal of Pathology 171 809-819. (doi:10.2353/ajpath.2007.070101)

Bunda S, Wang Y, Mitts TF, Liu P, Arab S, Arabkhari M \& Hinek A 2009 Aldosterone stimulates elastogenesis in cardiac fibroblasts via mineralocorticoid receptor-independent action involving the consecutive activation of Galpha13, c-Src, the insulin-like growth factor-I receptor, and phosphatidylinositol 3-kinase/Akt. Journal of Biological Chemistry 284 16633-16647. (doi:10.1074/jbc.M109.008748)

Butterworth MB 2010 Regulation of the epithelial sodium channel (ENaC) by membrane trafficking. Biochimica et Biophysica Acta 1802 1166-1177. (doi:10.1016/j.bbadis.2010.03.010)

Callera GE, Touyz RM, Tostes RC, Yogi A, He Y, Malkinson S \& Schiffrin EL 2005 Aldosterone activates vascular p38MAP kinase and NADPH oxidase via c-Src. Hypertension 45 773-779. (doi:10.1161/01. HYP.0000154365.30593.d3)

Callera GE, Yogi A, Briones AM, Montezano AC, He Y, Tostes RC, Schiffrin EL \& Touyz RM 2011a Vascular proinflammatory responses by aldosterone are mediated via c-Src trafficking to cholesterol-rich microdomains: role of PDGFR. Cardiovascular Research 91 720-731. (doi:10.1093/cvr/cvr131)

Callera GE, Yogi A, Briones AM, Montezano AC, He Y, Tostes RC Schiffrin EL \& Touyz RM $2011 b$ Vascular proinflammatory responses by aldosterone are mediated via c-Src trafficking to cholesterol-rich microdomains: role of PDGFR. Cardiovascular Research 91 720-731. (doi:10.1093/cvr/cvr131)

Cannavo A, Liccardo D, Eguchi A, Elliott KJ, Traynham CJ, Ibetti J, Eguchi S, Leosco D, Ferrara N, Rengo G, et al. 2016 Myocardial pathology induced by aldosterone is dependent on non-canonical activities of G protein-coupled receptor kinases. Nature Communications 7 10877. (doi:10.1038/ncomms10877)

Caprio M, Newfell BG, la Sala A, Baur W, Fabbri A, Rosano G, Mendelsohn ME \& Jaffe IZ 2008 Functional mineralocorticoid receptors in human vascular endothelial cells regulate intercellular adhesion molecule-1 expression and promote leukocyte adhesion. Circulation Research 102 1359-1367. (doi:10.1161/CIRCRESAHA. 108.174235)

Carreno JE, Verdugo FJ, Contreras F, Montellano FA, Veloso S, Schalper KA, Sandoval M, Villanueva S, Marusic E \& Irarrazabal CE 2015 Spironolactone inhibits the activity of the $\mathrm{Na}+\mathrm{H}+$ exchanger in the aorta of mineralocorticoid-induced hypertensive rats. Journal of the Renin-Angiotensin-Aldosterone System 16 1225-1231. (doi:10.1177/1470320315587193)

Cascella T, Radhakrishnan Y, Maile LA, Busby WH Jr, Gollahon K, Colao A \& Clemmons DR 2010 Aldosterone enhances IGF-I-mediated signaling and biological function in vascular smooth muscle cells. Endocrinology 151 5851-5864. (doi:10.1210/en.2010-0350)

Catena C, Colussi G, Nadalini E, Chiuch A, Baroselli S, Lapenna R \& Sechi LA 2008 Cardiovascular outcomes in patients with primary aldosteronism after treatment. Archives of Internal Medicine $\mathbf{1 6 8}$ 80-85. (doi:10.1001/archinternmed.2007.33)

Chen SY, Bhargava A, Mastroberardino L, Meijer OC, Wang J, Buse P, Firestone GL, Verrey F \& Pearce D 1999 Epithelial sodium channel regulated by aldosterone-induced protein sgk. PNAS 96 2514-2519. (doi:10.1073/pnas.96.5.2514)

Chen D, Chen Z, Park C, Centrella M, McCarthy T, Chen L, Al-Omari A \& Moeckel GW 2013 Aldosterone stimulates fibronectin synthesis in renal fibroblasts through mineralocorticoid receptor-dependent and independent mechanisms. Gene 531 23-30. (doi:10.1016/j. gene.2013.08.047)

Chen J, Gomez-Sanchez CE, Penman A, May PJ \& Gomez-Sanchez E 2014 Expression of mineralocorticoid and glucocorticoid receptors in preautonomic neurons of the rat paraventricular nucleus. American Journal of Physiology: Regulatory, Integrative and Comparative Physiology 306 R328-R340. (doi:10.1152/ajpcell.00249.2013)

Chen L, Ding ML, Wu F, He W, Li J, Zhang XY, Xie WL, Duan SZ, Xia WH \& Tao J 2016 Impaired endothelial repair capacity of early endothelial progenitor cells in hypertensive patients with primary hyperaldosteronemia: role of 5,6,7,8-tetrahydrobiopterin oxidation and endothelial nitric oxide synthase uncoupling. Hypertension 67 430-439. (doi:10.1161/hypertensionaha.115.06597)

Cheng SB, Dong J, Pang Y, LaRocca J, Hixon M, Thomas P \& Filardo EJ 2014 Anatomical location and redistribution of $G$ protein-coupled estrogen receptor-1 during the estrus cycle in mouse kidney and specific binding to estrogens but not aldosterone. Molecular and Cellular Endocrinology 382 950-959. (doi:10.1016/j.mce.2013.11.005)

Christ M, Sippel K, Eisen C \& Wehling M 1994 Non-classical receptors for aldosterone in plasma membranes from pig kidneys. Molecular and Cellular Endocrinology 99 R31-R34. (doi:10.1016/03037207(94)90027-2)

Christ M, Günther A, Heck M, Schmidt BMW, Falkenstein E \& Wehling M 1999 Aldosterone, not estradiol, is the physiological agonist for rapid increases in cAMP in vascular smooth muscle cells. Circulation 99 1485-1491. (doi:10.1161/01.CIR.99.11.1485)

Christy C, Hadoke PWF, Paterson JM, Mullins JJ, Seckl JR \& Walker BR $200311 \beta$-Hydroxysteroid dehydrogenase type 2 in mouse aorta: localization and influence on response to glucocorticoids. Hypertension 42 580-587. (doi:10.1161/01.HYP.0000088855.06598.5B)

Coelho-Filho OR, Shah RV, Neilan TG, Mitchell R, Moreno H Jr, Kwong R \& Jerosch-Herold M 2014 Cardiac magnetic resonance assessment of interstitial myocardial fibrosis and cardiomyocyte hypertrophy in hypertensive mice treated with spironolactone. Journal of the American Heart Association 3 e000790. (doi:10.1161/JAHA.114.000790)

Cole TJ, Terella L, Morgan J, Alexiadis M, Yao YZ, Enriori P, Young MJ \& Fuller PJ 2015 Aldosterone-mediated renal sodium transport requires intact mineralocorticoid receptor DNA-binding in the mouse. Endocrinology 156 2958-2968. (doi:10.1210/en.2015-1008)

Collins BJ, Deak M, Arthur JS, Armit LJ \& Alessi DR 2003 In vivo role of the PIF-binding docking site of PDK1 defined by knock-in mutation. EMBO Journal 22 4202-4211. (doi:10.1093/emboj/cdg407)

Darmellah A, Baetz D, Prunier F, Tamareille S, Rucker-Martin C \& Feuvray D 2007 Enhanced activity of the myocardial Na+/H+ exchanger contributes to left ventricular hypertrophy in the GotoKakizaki rat model of type 2 diabetes: critical role of Akt. Diabetologia 50 1335-1344. (doi:10.1007/s00125-007-0628-x)

Daughaday WH \& Rendleman D 1967 Severe symptomatic hyperkalemia in an adrenalectomized woman due to enhanced mineralocorticoid requirement. Annals of Internal Medicine 66 1197-1203. (doi:10.7326/0003-4819-66-6-1197)

Dave-Sharma S, Wilson RC, Harbison MD, Newfield R, Azar MR, Krozowski ZS, Funder JW, Shackleton CH, Bradlow HL, Wei JQ, et al.

Published by Bioscientifica Ltd. 
1998 Examination of genotype and phenotype relationships in 14 patients with apparent mineralocorticoid excess. Journal of Clinical Endocrinology and Metabolism 83 2244-2254. (doi:10.1210/ jc.83.7.2244)

De Giusti VC, Nolly MB, Yeves AM, Caldiz CI, Villa-Abrille MC, Chiappe de Cingolani GE, Ennis IL, Cingolani HE \& Aiello EA 2011 Aldosterone stimulates the cardiac $\mathrm{Na}(+) / \mathrm{H}(+)$ exchanger via transactivation of the epidermal growth factor receptor. Hypertension 58 912-919. (doi:10.1161/HYPERTENSIONAHA.111.176024)

De Giusti VC, Orlowski A, Ciancio MC, Espejo MS, Gonano LA, Caldiz CI, Vila Petroff MG, Villa-Abrille MC \& Aiello EA 2015 Aldosterone stimulates the cardiac sodium/bicarbonate cotransporter via activation of the g protein-coupled receptor gpr30. Journal of Molecular and Cellular Cardiology 89 260-267. (doi:10.1016/j.yjmcc.2015.10.024)

Delyani JA, Robinson EL \& Rudolph AE 2001 Effect of a selective aldosterone receptor antagonist in myocardial infarction. American Journal of Physiology: Heart and Circulatory Physiology 281 H647-H654.

Diakov A \& Korbmacher C 2004 A novel pathway of epithelial sodium channel activation involves a serum- and glucocorticoid-inducible kinase consensus motif in the C terminus of the channel's alphasubunit. Journal of Biological Chemistry 279 38134-38142. (doi:10.1074/jbc.M403260200)

Diaz RG, Perez NG, Morgan PE, Villa-Abrille MC, Caldiz CI, Nolly MB, Portiansky EL, Ennis IL \& Cingolani HE 2014 Myocardial mineralocorticoid receptor activation by stretching and its functional consequences. Hypertension 63 112-118. (doi:10.1161/ HYPERTENSIONAHA.113.01726)

Ding W, Yang L, Zhang M \& Gu Y 2012 Chronic inhibition of nuclear factor kappa B attenuates aldosterone/salt-induced renal injury. Life Science 90 600-606. (doi:10.1016/j.lfs.2012.02.022)

Dooley R, Angibaud E, Yusef YR, Thomas W \& Harvey BJ 2013 Aldosterone-induced $\mathrm{ENaC}$ and basal $\mathrm{Na}+/ \mathrm{K}+$-ATPase trafficking via protein kinase D1-phosphatidylinositol 4-kinaseIIIbeta trans Golgi signalling in M1 cortical collecting duct cells. Molecular and Cellular Endocrinology 372 86-95. (doi:10.1016/j.mce.2013.03.011)

Doucet A \& Katz AI 1981 Mineralcorticoid receptors along the nephron: $[3 \mathrm{H}]$ aldosterone binding in rabbit tubules. American Journal of Physiology 241 F605-F611.

Eatman D, Peagler K, Watson J, Rollins-Hairston A \& Bayorh MA 2011 The involvement of prostaglandins in the contractile function of the aorta by aldosterone. BMC Research Notes 4 125. (doi:10.1186/17560500-4-125)

Edelman IS, Bogoroch R \& Porter GA 1963 On the mechanism of action of aldosterone on sodium transport: the role of protein synthesis. PNAS 50 1169-1177. (doi:10.1073/pnas.50.6.1169)

Eladari D, Chambrey R \& Peti-Peterdi J 2012 A new look at electrolyte transport in the distal tubule. Annual Review of Physiology $\mathbf{7 4}$ 325-349. (doi:10.1146/annurev-physiol-020911-153225)

Enomoto S, Yoshiyama M, Omura T, Matsumoto R, Kusuyama T, Kim S, Izumi Y, Akioka K, Iwao H, Takeuchi K, et al. 2005 Effects of eplerenone on transcriptional factors and mRNA expression related to cardiac remodelling after myocardial infarction. Heart 91 1595-1600. (doi:10.1136/hrt.2004.046540)

Faresse N, Lagnaz D, Debonneville A, Ismailji A, Maillard M, FejesToth G, Naray-Fejes-Toth A \& Staub O 2012 Inducible kidney-specific Sgk1 knockout mice show a salt-losing phenotype. American Journal of Physiology: Renal Physiology 302 F977-F985. (doi:10.1152/ ajprenal.00535.2011)

Farman N, Vandewalle A \& Bonvalet JP 1982 Aldosterone binding in isolated tubules I. Biochemical determination in proximal and distal parts of the rabbit nephron. American Journal of Physiology 242 F63-F68.

Feldman RD \& Limbird LE 2015 Copernicus revisited: overturning Ptolemy's view of the GPER universe. Trends in Endocrinology and Metabolism 26 592-594. (doi:10.1016/j.tem.2015.09.002)

Félétou M, Huang Y \& Vanhoutte PM 2011 Endothelium-mediated control of vascular tone: COX-1 and COX-2 products. British
Journal of Pharmacology 164 894-912. (doi:10.1111/j.14765381.2011.01276.x)

Fiebeler A, Schmidt F, Muller DN, Park JK, Dechend R, Bieringer M, Shagdarsuren E, Breu V, Haller H \& Luft FC 2001 Mineralocorticoid receptor affects AP-1 and nuclear factor-kappab activation in angiotensin II-induced cardiac injury. Hypertension 37 787-793. (doi:10.1161/01.HYP.37.2.787)

Filardo EJ, Quinn JA, Bland KI \& Frackelton AR Jr 2000 Estrogeninduced activation of Erk-1 and Erk-2 requires the G protein-coupled receptor homolog, GPR30, and occurs via trans-activation of the epidermal growth factor receptor through release of HB-EGF. Molecular Endocrinology 14 1649-1660. (doi:10.1210/ mend.14.10.0532)

Fine D, Meiselas LE \& Auerbach T 1958 The effect of acute hypovolemia on the release of aldosterone and on the renal excretion of sodium. Journal of Clinical Investigation 37 232-243. (doi:10.1172/JCI103602)

Fiore C, Sartorato P, Pagnin E, Ragazzi E, Calo LA \& Armanini D 2009 Effect of canrenone and amiloride on the prooxidative effect induced by aldosterone in human mononuclear leukocytes in vitro. Journal of Endocrinological Investigation 32 895-898. (doi:10.1007/BF03345768)

Forrester SJ, Kawai T, O'Brien S, Thomas W, Harris RC \& Eguchi S 2016 Epidermal growth factor receptor transactivation: mechanisms, pathophysiology, and potential therapies in the cardiovascular system. Annual Review of Pharmacology and Toxicology 56 627-653. (doi:10.1146/annurev-pharmtox-070115-095427)

Förstermann U \& Münzel T 2006 Endothelial nitric oxide synthase in vascular disease: from marvel to menace. Circulation 113 1708-1714. (doi:10.1161/circulationaha.105.602532)

Fu GX, Xu CC, Zhong Y, Zhu DL \& Gao PJ 2012 Aldosterone-induced osteopontin expression in vascular smooth muscle cells involves MR, ERK, and p38 MAPK. Endocrine 42 676-683. (doi:10.1007/s12020012-9675-2)

Fujisawa G, Okada K, Muto S, Fujita N, Itabashi N, Kusano E \& Ishibashi S $2003 \mathrm{Na} / \mathrm{H}$ exchange isoform 1 is involved in mineralocorticoid/salt-induced cardiac injury. Hypertension $\mathbf{4 1}$ 493-498. (doi:10.1161/01.HYP.0000056769.73726.E5)

Funder JW, Pearce PT, Smith R \& Smith AI 1988 Mineralocorticoid action: target tissue specificity is enzyme, not receptor, mediated. Science 242 583-585. (doi:10.1126/science.2845584)

Galigniana MD, Echeverria PC, Erlejman AG \& Piwien-Pilipuk G 2010a Role of molecular chaperones and TPR-domain proteins in the cytoplasmic transport of steroid receptors and their passage through the nuclear pore. Nucleus 1 299-308. (doi:10.4161/nucl.1.4.11743)

Galigniana MD, Erlejman AG, Monte M, Gomez-Sanchez C \& PiwienPilipuk G $2010 b$ The hsp90-FKBP52 complex links the mineralocorticoid receptor to motor proteins and persists bound to the receptor in early nuclear events. Molecular and Cellular Biology 30 1285-1298. (doi:10.1128/MCB.01190-09)

Gallo LI, Ghini AA, Piwien Pilipuk G \& Galigniana MD 2007 Differential recruitment of tetratricorpeptide repeat domain immunophilins to the mineralocorticoid receptor influences both heat-shock protein 90-dependent retrotransport and hormone-dependent transcriptional activity. Biochemistry 46 14044-14057. (doi:10.1021/bi701372c)

Galmiche G, Pizard A, Gueret A, El Moghrabi S, Ouvrard-Pascaud A, Berger S, Challande P, Jaffe IZ, Labat C, Lacolley P, et al. 2014 Smooth muscle cell mineralocorticoid receptors are mandatory for aldosterone-salt to induce vascular stiffness. Hypertension $\mathbf{6 3}$ 520-526. (doi:10.1161/HYPERTENSIONAHA.113.01967)

Gamba G, Miyanoshita A, Lombardi M, Lytton J, Lee WS, Hediger MA \& Hebert SC 1994 Molecular cloning, primary structure, and characterization of two members of the mammalian electroneutral sodium-(potassium)-chloride cotransporter family expressed in kidney. Journal of Biological Chemistry 269 17713-17722.

Gekle M, Freudinger R, Mildenberger S, Schenk K, Marschitz I \& Schramek H 2001 Rapid activation of $\mathrm{Na}+\mathrm{H}+$-exchange in MDCK

Published by Bioscientifica Ltd. 
cells by aldosterone involves MAP-kinase ERK1/2. Pflugers Archiv: European Journal of Physiology 441 781-786. (doi:10.1007) s004240000507)

Gekle M, Freudinger R, Mildenberger S \& Silbernagl S 2002 Aldosterone interaction with epidermal growth factor receptor signaling in MDCK cells. American Journal of Physiology: Renal Physiology $\mathbf{2 8 2}$ F669-F679. (doi:10.1152/ajprenal.00159.2001)

Ghigo A \& Li M 2015 Phosphoinositide 3-kinase: friend and foe in cardiovascular disease. Frontiers in Pharmacology 6 169. (doi:10.3389/ fphar.2015.00169)

Gilet A, Zou F, Boumenir M, Frippiat JP, Thornton SN, Lacolley P \& Ropars A 2015 Aldosterone up-regulates MMP-9 and MMP-9/NGAL expression in human neutrophils through p38, ERK1/2 and PI3K pathways. Experimental Cell Research 331 152-163. (doi:10.1016/j. yexcr.2014.11.004)

Gomez-Sanchez EP, Ahmad N, Romero DG \& Gomez-Sanchez CE 2004 Origin of aldosterone in the rat heart. Endocrinology 145 4796-4802. (doi:10.1210/en.2004-0295)

Gomez AM, Rueda A, Sainte-Marie Y, Pereira L, Zissimopoulos S, Zhu X, Schaub R, Perrier E, Perrier R, Latouche C, et al. 2009 Mineralocorticoid modulation of cardiac ryanodine receptor activity is associated with downregulation of FK506-binding proteins. Circulation 119 2179-2187. (doi:10.1161/CIRCULATIONAHA.108.805804)

Gong R, Morris DJ \& Brem AS 2008 Variable expression of 11beta Hydroxysteroid dehydrogenase (11beta-HSD) isoforms in vascular endothelial cells. Steroids 73 1187-1196. (doi:10.1016/j. steroids.2008.05.009)

Goulopoulou S \& Webb RC 2014 The symphony of vascular contraction: How smooth muscle cells lose harmony to signal increased vascular resistance in hypertension. Hypertension 63 e33-e39. (doi:10.1161/ HYPERTENSIONAHA.113.02444)

Gros R, Ding Q, Davis M, Shaikh R, Liu B, Chorazyczewski J, Pickering JG \& Feldman RD 2011a Delineating the receptor mechanisms underlying the rapid vascular contractile effects of aldosterone and estradiol. Canadian Journal of Physiology and Pharmacology 89 655-663. (doi:10.1139/y11-062)

Gros R, Ding Q, Sklar LA, Prossnitz EE, Arterburn JB, Chorazyczewski J \& Feldman RD $2011 b$ GPR30 expression is required for the mineralocorticoid receptor-independent rapid vascular effects of aldosterone. Hypertension 57 442-451. (doi:10.1161/ HYPERTENSIONAHA.110.161653)

Gros R, Ding Q, Liu B, Chorazyczewski J \& Feldman RD 2013 Aldosterone mediates its rapid effects in vascular endothelial cells through GPER activation. American Journal of Physiology: Cell Physiology 304 C532-C540. (doi:10.1152/ajpcell.00203.2012)

Grossmann C, Freudinger R, Mildenberger S, Krug AW \& Gekle M 2004 Evidence for epidermal growth factor receptor as negative-feedback control in aldosterone-induced $\mathrm{Na}+$ reabsorption. American Journal of Physiology: Renal Physiology 286 F1226-F1231. (doi:10.1152/ ajprenal.00378.2003)

Grossmann C, Benesic A, Krug AW, Freudinger R, Mildenberger S, Gassner B \& Gekle M 2005 Human mineralocorticoid receptor expression renders cells responsive for nongenotropic aldosterone actions. Molecular Endocrinology 19 1697-1710. (doi:10.1210/ me.2004-0469)

Grossmann C, Ruhs S, Langenbruch L, Mildenberger S, Stratz N, Schumann K \& Gekle M 2012 Nuclear shuttling precedes dimerization in mineralocorticoid receptor signaling. Chemistry and Biology 19 742-751. (doi:10.1016/j.chembiol.2012.04.014)

Han JS, Choi BS, Yang CW \& Kim YS 2009 Aldosterone-induced TGFbeta1 expression is regulated by mitogen-activated protein kinases and activator protein-1 in mesangial cells. Journal of Korean Medical Science 24 (Supplement) S195-S203. (doi:10.3346/jkms.2009.24.S1.S195)

Harada E, Yoshimura M, Yasue H, Nakagawa O, Nakagawa M, Harada M, Mizuno Y, Nakayama M, Shimasaki Y, Ito T, et al. 2001 Aldosterone induces angiotensin-converting-enzyme gene expression in cultured neonatal rat cardiocytes. Circulation 104 137-139. (doi:10.1161/01. CIR.104.2.137)

Hashikabe Y, Suzuki K, Jojima T, Uchida K \& Hattori Y 2006 Aldosterone impairs vascular endothelial cell function. Journal of Cardiovascular Pharmacology 47 609-613. (doi:10.1097/01.fjc.0000211738.63207.c3)

Hatakeyama H, Inaba S \& Miyamori I 2001 11beta-hydroxysteroid dehydrogenase activity in human aortic smooth muscle cells. Hypertension Research: Clinical and Experimental 24 33-37. (doi:10.1291/hypres.24.33)

Hausser A, Storz P, Martens S, Link G, Toker A \& Pfizenmaier K 2005 Protein kinase D regulates vesicular transport by phosphorylating and activating phosphatidylinositol-4 kinase IIIbeta at the Golgi complex. Nature Cell Biology 7 880-886. (doi:10.1038/ncb1289)

Hayashi H, Kobara M, Abe M, Tanaka N, Gouda E, Toba H, Yamada H, Tatsumi T, Nakata T \& Matsubara H 2008 Aldosterone nongenomically produces NADPH oxidase-dependent reactive oxygen species and induces myocyte apoptosis. Hypertension Research: Clinical and Experimental 31 363-375. (doi:10.1291/hypres.31.363)

He BJ, Joiner ML, Singh MV, Luczak ED, Swaminathan PD, Koval OM, Kutschke W, Allamargot C, Yang J, Guan X, et al. 2011 Oxidation of CaMKII determines the cardiotoxic effects of aldosterone. Nature Medicine 17 1610-1618. (doi:10.1038/nm.2506)

Hellal-Levy C, Fagart J, Souque A \& Rafestin-Oblin ME 2000 Mechanistic aspects of mineralocorticoid receptor activation. Kidney International 57 1250-1255. (doi:10.1046/j.1523-1755.2000.00958.x)

Hendron E \& Stockand JD 2002 Activation of mitogen-activated protein kinase (mitogen-activated protein kinase/extracellular signalregulated kinase) cascade by aldosterone. Molecular Biology of the Cell 13 3042-3054. (doi:10.1091/mbc.E02-05-0260)

Hewitt KN, Walker EA \& Stewart PM 2005 Minireview: hexose-6phosphate dehydrogenase and redox control of 11 beta\}hydroxysteroid dehydrogenase type 1 activity. Endocrinology 146 2539-2543. (doi:10.1210/en.2005-0117)

Hirono Y, Yoshimoto T, Suzuki N, Sugiyama T, Sakurada M, Takai S, Kobayashi N, Shichiri M \& Hirata Y 2007 Angiotensin II receptor type 1-mediated vascular oxidative stress and proinflammatory gene expression in aldosterone-induced hypertension: the possible role of local renin-angiotensin system. Endocrinology 148 1688-1696. (doi:10.1210/en.2006-1157)

Hofmeister MV, Damkier HH, Christensen BM, Olde B, Fredrik LeebLundberg LM, Fenton RA, Praetorius HA \& Praetorius J 2012 $17 \beta$-Estradiol induces nongenomic effects in renal intercalated cells through G protein-coupled estrogen receptor 1. American Journal of Physiology: Renal Physiology 302 F358-F368. (doi:10.1152/ ajprenal.00343.2011)

Holzman JL, Liu L, Duke BJ, Kemendy AE \& Eaton DC 2007 Transactivation of the IGF-1R by aldosterone. American Journal of Physiology: Renal Physiology 292 F1219-F1228. (doi:10.1152/ ajprenal.00214.2006)

Huang S, Zhang A, Ding G \& Chen R 2009 Aldosterone-induced mesangial cell proliferation is mediated by EGF receptor transactivation. American Journal of Physiology: Renal Physiology 296 F1323-F1333. (doi:10.1152/ajprenal.90428.2008)

Huang LL, Nikolic-Paterson DJ, Ma FY \& Tesch GH 2012 Aldosterone induces kidney fibroblast proliferation via activation of growth factor receptors and PI3K/MAPK signalling. Nephron Experimental Nephrology 120 e115-e122. (doi:10.1159/000339500)

Hudson WH, Youn C \& Ortlund EA 2014 Crystal structure of the mineralocorticoid receptor DNA binding domain in complex with DNA. PLOS ONE 9 e107000. (doi:10.1371/journal.pone.0107000)

Hui E, Yeung MC, Cheung PT, Kwan E, Low L, Tan KC, Lam KS \& Chan AO 2014 The clinical significance of aldosterone synthase deficiency: report of a novel mutation in the CYP11B2 gene. BMC Endocrine Disorders 14 29. (doi:10.1186/1472-6823-14-29)

Huyet J, Pinon GM, Fay MR, Rafestin-Oblin ME \& Fagart J 2012 Structural determinants of ligand binding to the mineralocorticoid 
receptor. Molecular and Cellular Endocrinology 350 187-195. (doi:10.1016/j.mce.2011.07.035)

Iqbal J, Andrew R, Cruden NL, Kenyon CJ, Hughes KA, Newby DE, Hadoke PW \& Walker BR 2014 Displacement of cortisol from human heart by acute administration of a mineralocorticoid receptor antagonist. Journal of Clinical Endocrinology and Metabolism 99 915-922. (doi:10.1210/jc.2013-2049)

Iwashima F, Yoshimoto T, Minami I, Sakurada M, Hirono Y \& Hirata Y 2008 Aldosterone induces superoxide generation via Rac1 activation in endothelial cells. Endocrinology 149 1009-1014. (doi:10.1210/ en.2007-0864)

Jaffe IZ \& Mendelsohn ME 2005 Angiotensin II and aldosterone regulate gene transcription via functional mineralocortocoid receptors in human coronary artery smooth muscle cells. Circulation Research 96 643-650. (doi:10.1161/01.RES.0000159937.05502.d1)

Jeong Y, Chaupin DF, Matsushita K, Yamakuchi M, Cameron SJ, Morrell CN \& Lowenstein CJ 2009 Aldosterone activates endothelia exocytosis. PNAS 106 3782-3787. (doi:10.1073/pnas.0804037106)

Jessup JA, Lindsey SH, Wang H, Chappell MC \& Groban L 2010 Attenuation of salt-induced cardiac remodeling and diastolic dysfunction by the GPER agonist G-1 in female mRen2.Lewis rats. PLOS ONE 5 e15433. (doi:10.1371/journal.pone.0015433)

Kawarazaki W, Nagase M, Yoshida S, Takeuchi M, Ishizawa K, Ayuzawa N, Ueda K \& Fujita T 2012 Angiotensin II- and salt-induced kidney injury through Rac1-mediated mineralocorticoid receptor activation. Journal of the American Society of Nephrology 23 997-1007. (doi:10.1681/ASN.2011070734)

Keidar S, Kaplan M, Pavlotzky E, Coleman R, Hayek T, Hamoud S \& Aviram M 2004 Aldosterone administration to mice stimulates macrophage NADPH oxidase and increases atherosclerosis development: a possible role for angiotensin-converting enzyme and the receptors for angiotensin II and aldosterone. Circulation 109 2213-2220. (doi:10.1161/01.CIR.0000127949.05756.9D)

Kellenberger S \& Schild L 2002 Epithelial sodium channel/degenerin family of ion channels: a variety of functions for a shared structure. Physiological Reviews 82 735-767. (doi:10.1152/ physrev.00007.2002)

Kenouch S, Lombes M, Delahaye F, Eugene E, Bonvalet JP \& Farman N 1994 Human skin as target for aldosterone: coexpression of mineralocorticoid receptors and 11 beta-hydroxysteroid dehydrogenase. Journal of Clinical Endocrinology and Metabolism 79 1334-1341. (doi:10.1210/jc.79.5.1334)

Kirsch T, Beese M, Wyss K, Klinge U, Haller H, Haubitz M \& Fiebeler A 2013 Aldosterone modulates endothelial permeability and endothelial nitric oxide synthase activity by rearrangement of the actin cytoskeleton. Hypertension 61 501-508. (doi:10.1161/ HYPERTENSIONAHA.111.196832)

Ko B, Mistry AC, Hanson L, Mallick R, Wynne BM, Thai TL, Bailey JL, Klein JD \& Hoover RS 2013 Aldosterone acutely stimulates NCC activity via a SPAK-mediated pathway. American Journal of Physiology: Renal Physiology 305 F645-F652. (doi:10.1152/ajprenal.00053.2013)

Kolla V, Robertson NM \& Litwack G 1999 Identification of a mineralocorticoid/glucocorticoid response element in the human $\mathrm{Na} / \mathrm{K}$ ATPase alpha1 gene promoter. Biochemical and Biophysical Research Communications 266 5-14. (doi:10.1006/bbrc.1999.1765)

Konishi H, Kuroda S, Inada Y \& Fujisawa Y 1994 Novel subtype of human angiotensin II type 1 receptor: cDNA cloning and expression. Biochemical and Biophysical Research Communications 199 467-474. (doi:10.1006/bbrc.1994.1252)

Korichneva I, Puceat M, Millanvoye-Van Brussel E, Geraud G \& Vassort G 1995 Aldosterone modulates both the $\mathrm{Na} / \mathrm{H}$ antiport and $\mathrm{Cl} / \mathrm{HCO} 3$ exchanger in cultured neonatal rat cardiac cells. Journal of Molecular and Cellular Cardiology 27 2521-2528. (doi:10.1006/ jmcc.1995.0239)
Koster M \& David GK 1968 Reversible severe hypertension due to licorice ingestion. New England Journal of Medicine 278 1381-1383. (doi:10.1056/NEJM196806202782505)

Krug AW, Grossmann C, Schuster C, Freudinger R, Mildenberger S, Govindan MV \& Gekle M 2003 Aldosterone stimulates epidermal growth factor receptor expression. Journal of Biological Chemistry 278 43060-43066. (doi:10.1074/jbc.M308134200)

Labuzek K, Liber S, Buldak L, Machnik G, Liber J \& Okopien B 2013 Eplerenone promotes alternative activation in human monocytederived macrophages. Pharmacological Reports 65 226-234. (doi:10.1016/S1734-1140(13)70983-6)

Lalevee N, Rebsamen MC, Barrere-Lemaire S, Perrier E, Nargeot J, Benitah JP \& Rossier MF 2005 Aldosterone increases T-type calcium channel expression and in vitro beating frequency in neonatal rat cardiomyocytes. Cardiovascular Research 67 216-224. (doi:10.1016/j. cardiores.2005.05.009)

Latouche C, Sainte-Marie Y, Steenman M, Castro Chaves P, Naray-FejesToth A, Fejes-Toth G, Farman N \& Jaisser F 2010 Molecular signature of mineralocorticoid receptor signaling in cardiomyocytes: from cultured cells to mouse heart. Endocrinology 151 4467-4476. (doi:10.1210/en.2010-0237)

Latouche C, El Moghrabi S, Messaoudi S, Nguyen Dinh Cat A, Hernandez-Diaz I, Alvarez de la Rosa D, Perret C, Lopez Andres N, Rossignol P, Zannad F, et al. 2012 Neutrophil gelatinase-associated lipocalin is a novel mineralocorticoid target in the cardiovascular system. Hypertension 59 966-972. (doi:10.1161/ HYPERTENSIONAHA.111.187872)

Le Billan F, Khan JA, Lamribet K, Viengchareun S, Bouligand J, Fagart J \& Lombes M 2015 Cistrome of the aldosterone-activated mineralocorticoid receptor in human renal cells. FASEB Journal 29 3977-3989. (doi:10.1016/j.febslet.2015.11.028)

Le Moellic C, Ouvrard-Pascaud A, Capurro C, Cluzeaud F, Fay M, Jaisser F, Farman N \& Blot-Chabaud M 2004 Early nongenomic events in aldosterone action in renal collecting duct cells: PKCalpha activation, mineralocorticoid receptor phosphorylation, and crosstalk with the genomic response. Journal of the American Society of Nephrology 15 1145-1160.

Lee YS, Kim JA, Kim KL, Jang HS, Kim JM, Lee JY, Shin IS, Lee JS, Suh W, Choi JH, et al. 2004 Aldosterone upregulates connective tissue growth factor gene expression via p38 MAPK pathway and mineralocorticoid receptor in ventricular myocytes. Journal of Korean Medical Science 19 805-811. (doi:10.3346/jkms.2004.19.6.805)

Lemarie CA, Simeone SM, Nikonova A, Ebrahimian T, Deschenes ME, Coffman TM, Paradis P \& Schiffrin EL 2009 Aldosterone-induced activation of signaling pathways requires activity of angiotensin type 1a receptors. Circulation Research 105 852-859. (doi:10.1161/ CIRCRESAHA.109.196576)

Leopold JA, Dam A, Maron BA, Scribner AW, Liao R, Handy DE, Stanton RC, Pitt B \& Loscalzo J 2007 Aldosterone impairs vascular reactivity by decreasing glucose-6-phosphate dehydrogenase activity. Nature Medicine 13 189-197. (doi:10.1038/nm1545)

Leroy V, De Seigneux S, Agassiz V, Hasler U, Rafestin-Oblin ME, Vinciguerra M, Martin PY \& Feraille E 2009 Aldosterone activates NF-kappaB in the collecting duct. Journal of the American Society of Nephrology 20 131-144. (doi:10.1681/ASN.2008020232)

Li Y, Suino K, Daugherty J \& Xu HE 2005 Structural and biochemical mechanisms for the specificity of hormone binding and coactivator assembly by mineralocorticoid receptor. Molecular Cell 19 367-380. (doi:10.1016/j.molcel.2005.06.026)

Li C, Zhang YY, Frieler RA, Zheng XJ, Zhang WC, Sun XN, Yang QZ, Ma SM, Huang B, Berger S, et al. 2014 Myeloid mineralocorticoid receptor deficiency inhibits aortic constriction-induced cardiac hypertrophy in mice. PLOS ONE 9 e110950. (doi:10.1371/journal. pone.0110950 http://jme.endocrinology-journals.org

DOI: 10.1530/JME-15-0318
() 2017 Society for Endocrinology Printed in Great Britain
Published by Bioscientifica Ltd 
Lim-Tio SS, Keightley MC \& Fuller PJ 1997 Determinants of specificity of transactivation by the mineralocorticoid or glucocorticoid receptor. Endocrinology 138 2537-2543. (doi:10.1210/en.138.6.2537)

Lipscombe D 2002 L-Type calcium channels: highs and new lows. Circulation Research 90 933-935. (doi:10.1161/01. RES.0000019740.52306.92)

Liu SL, Schmuck S, Chorazcyzewski JZ, Gros R \& Feldman RD 2003 Aldosterone regulates vascular reactivity: short-term effects mediated by phosphatidylinositol 3-kinase-dependent nitric oxide synthase activation. Circulation 108 2400-2406. (doi:10.1161/01. CIR.0000093188.53554.44)

Liu Y, Mladinov D, Pietrusz JL, Usa K \& Liang M 2009 Glucocorticoid response elements and 11 $\beta$-hydroxysteroid dehydrogenases in the regulation of endothelial nitric oxide synthase expression. Cardiovascular Research 81 140-147. (doi:10.1093/cvr/cvn231)

Loffing J \& Korbmacher C 2009 Regulated sodium transport in the renal connecting tubule (CNT) via the epithelial sodium channel (ENaC). Pflugers Archiv: European Journal of Physiology 458 111-135. (doi:10.1007/s00424-009-0656-0)

Lombes M, Oblin ME, Gasc JM, Baulieu EE, Farman N \& Bonvalet JP 1992 Immunohistochemical and biochemical evidence for a cardiovascular mineralocorticoid receptor. Circulation Research $\mathbf{7 1}$ 503-510. (doi:10.1161/01.RES.71.3.503)

Lombes M, Alfaidy N, Eugene E, Lessana A, Farman N \& Bonvalet JP 1995 Prerequisite for cardiac aldosterone action. Mineralocorticoid receptor and 11 beta-hydroxysteroid dehydrogenase in the human heart. Circulation 92 175-182. (doi:10.1161/01.CIR.92.2.175)

Lother A, Berger S, Gilsbach R, Rosner S, Ecke A, Barreto F, Bauersachs J, Schutz G \& Hein L 2011 Ablation of mineralocorticoid receptors in myocytes but not in fibroblasts preserves cardiac function. Hypertension 57 746-754. (doi:10.1161/HYPERTENSIONAHA. 110.163287)

Mani O, Nashev LG, Livelo C, Baker ME \& Odermatt A 2016 Role of Pro-637 and Gln-642 in human glucocorticoid receptors and Ser-843 and Leu-848 in mineralocorticoid receptors in their differential responses to cortisol and aldosterone. Journal of Steroid Biochemistry and Molecular Biology 159 31-40. (doi:10.1016/j.jsbmb.2016.02.017)

Maron BA, Zhang YY, White K, Chan SY, Handy DE, Mahoney CE, Loscalzo J \& Leopold JA 2012 Aldosterone inactivates the endothelin-B receptor via a cysteinyl thiol redox switch to decrease pulmonary endothelial nitric oxide levels and modulate pulmonary arterial hypertension. Circulation 126 963-974. (doi:10.1161/ CIRCULATIONAHA.112.094722)

Martin-Fernandez B, de las Heras N, Miana M, Ballesteros S, Delgado C, Song S, Hintze T, Cachofeiro V \& Lahera V 2011 Structural, functional, and molecular alterations produced by aldosterone plus salt in rat heart: association with enhanced serum and glucocorticoid-regulated kinase-1 expression. Journal of Cardiovascular Pharmacology 57 114-121. (doi:10.1097/FJC.0b013e31820088ca)

Masilamani S, Kim GH, Mitchell C, Wade JB \& Knepper MA 1999 Aldosterone-mediated regulation of $\mathrm{ENaC}$ alpha, beta, and gamma subunit proteins in rat kidney. Journal of Clinical Investigation 104 R19-R23. (doi:10.1172/JCI7840)

Matsui S, Satoh H, Kawashima H, Nagasaka S, Niu CF, Urushida T, Katoh H, Watanabe Y \& Hayashi H 2007 Non-genomic effects of aldosterone on intracellular ion regulation and cell volume in rat ventricular myocytes. Canadian Journal of Physiology and Pharmacology 85 264-273. (doi:10.1139/Y07-017)

Mattiazzi A 1997 Positive inotropic effect of angiotensin II. Increases in intracellular $\mathrm{Ca} 2+$ or changes in myofilament $\mathrm{Ca} 2+$ responsiveness? Journal of Pharmacological and Toxicological Methods 37 205-214. (doi:10.1016/S1056-8719(97)00020-8)

McCurley A, Pires PW, Bender SB, Aronovitz M, Zhao MJ, Metzger D, Chambon P, Hill MA, Dorrance AM, Mendelsohn ME, et al. 2012 Direct regulation of blood pressure by smooth muscle cell mineralocorticoid receptors. Nature Medicine 18 1429-1433. (doi:10.1038/nm.2891)

McEneaney V, Harvey BJ \& Thomas W 2007 Aldosterone rapidly activates protein kinase $\mathrm{D}$ via a mineralocorticoid receptor/EGFR trans-activation pathway in the M1 kidney CCD cell line. Journal of Steroid Biochemistry and Molecular Biology 107 180-190. (doi:10.1016/j.jsbmb.2007.03.043)

McEneaney V, Harvey BJ \& Thomas W 2008 Aldosterone regulates rapid trafficking of epithelial sodium channel subunits in renal cortical collecting duct cells via protein kinase D activation. Molecular Endocrinology 22 881-892. (doi:10.1210/me.2007-0225)

McEneaney V, Dooley R, Harvey BJ \& Thomas W 2010a Protein kinase D stabilizes aldosterone-induced ERK1/2 MAP kinase activation in M1 renal cortical collecting duct cells to promote cell proliferation. Journal of Steroid Biochemistry and Molecular Biology 118 18-28. (doi:10.1016/j.jsbmb.2009.09.014)

McEneaney V, Dooley R, Yusef YR, Keating N, Quinn U, Harvey BJ \& Thomas W 2010b Protein kinase D1 modulates aldosterone-induced $\mathrm{ENaC}$ activity in a renal cortical collecting duct cell line. Molecular and Cellular Endocrinology 325 8-17. (doi:10.1016/j. mce.2010.04.019)

McGraw AP, Bagley J, Chen WS, Galayda C, Nickerson H, Armani A, Caprio M, Carmeliet P \& Jaffe IZ 2013 Aldosterone increases early atherosclerosis and promotes plaque inflammation through a placental growth factor-dependent mechanism. Journal of the American Heart Association 2 e000018. (doi:10.1161/ JAHA.112.000018)

Meinel S, Ruhs S, Schumann K, Stratz N, Trenkmann K, Schreier B, Grosse I, Keilwagen J, Gekle M \& Grossmann C 2013a Mineralocorticoid receptor interaction with SP1 generates a new response element for pathophysiologically relevant gene expression. Nucleic Acids Research 41 8045-8060. (doi:10.1093/nar/gkt581)

Meinel S, Ruhs S, Schumann K, Strätz N, Trenkmann K, Schreier B, Grosse I, Keilwagen J, Gekle M \& Grossmann C 2013b Mineralocorticoid receptor interaction with SP1 generates a new response element for pathophysiologically relevant gene expression. Nucleic Acids Research 41 8045-8060. (doi:10.1093/nar/gkt581)

Messaoudi S, Zhang AD, Griol-Charhbili V, Escoubet B, Sadoshima J, Farman N \& Jaisser F 2012 The epidermal growth factor receptor is involved in angiotensin II but not aldosterone/salt-induced cardiac remodelling. PLOS ONE 7 e30156. (doi:10.1371/journal. pone.0030156)

Mick VE, Itani OA, Loftus RW, Husted RF, Schmidt TJ \& Thomas CP 2001 The alpha-subunit of the epithelial sodium channel is an aldosterone-induced transcript in mammalian collecting ducts, and this transcriptional response is mediated via distinct cis-elements in the 5 '-flanking region of the gene. Molecular Endocrinology $\mathbf{1 5}$ 575-588. (doi:10.1210/mend.15.4.0620)

Mihailidou AS, Buhagiar KA \& Rasmussen HH $1998 \mathrm{Na}+$ influx and $\mathrm{Na}(+)-\mathrm{K}+$ pump activation during short-term exposure of cardiac myocytes to aldosterone. American Journal of Physiology $\mathbf{2 7 4}$ C175-C181.

Mihailidou AS, Bundgaard H, Mardini M, Hansen PS, Kjeldsen K \& Rasmussen HH 2000 Hyperaldosteronemia in rabbits inhibits the cardiac sarcolemmal $\mathrm{Na}(+)-\mathrm{K}(+)$ pump. Circulation Research 86 37-42. (doi:10.1161/01.RES.86.1.37)

Mihailidou AS, Mardini M \& Funder JW 2004 Rapid, nongenomic effects of aldosterone in the heart mediated by epsilon protein kinase C. Endocrinology 145 773-780. (doi:10.1210/en.2003-1137)

Mihailidou AS, Loan Le TY, Mardini M \& Funder JW 2009 Glucocorticoids activate cardiac mineralocorticoid receptors during experimental myocardial infarction. Hypertension 54 1306-1312. (doi:10.1161/HYPERTENSIONAHA.109.136242)

Milliez P, Girerd X, Plouin PF, Blacher J, Safar ME \& Mourad JJ 2005 Evidence for an increased rate of cardiovascular events in patients http://jme.endocrinology-journals.org

DOI: 10.1530/JME-15-0318
๑) 2017 Society for Endocrinology Printed in Great Britain
Published by Bioscientifica Ltd 
with primary aldosteronism. Journal of the American College of Cardiology 45 1243-1248. (doi:10.1016/j.jacc.2005.01.015)

Mirone G, Shukla A \& Marfe G 2015 Signaling mechanisms of resistance to EGFR- and Anti-Angiogenic Inhibitors cancer. Critical Reviews in Oncology/Hematology 97 85-95. (doi:10.1016/j.critrevonc.2015.08.012)

Miyata K, Rahman M, Shokoji T, Nagai Y, Zhang GX, Sun GP, Kimura S, Yukimura T, Kiyomoto H, Kohno M, et al. 2005a Aldosterone stimulates reactive oxygen species production through activation of NADPH oxidase in rat mesangial cells. Journal of the American Society of Nephrology 16 2906-2912. (doi:10.1681/ASN.2005040390)

Miyata Y, Muto S \& Kusano E 2005b Mechanisms for nongenomic and genomic effects of aldosterone on $\mathrm{Na}+\mathrm{H}+$ exchange in vascular smooth muscle cells. Journal of Hypertension 23 2237-2250. (doi:10.1097/01.hjh.0000194122.27475.6c)

Montezano AC, Callera GE, Yogi A, He Y, Tostes RC, He G, Schiffrin EL \& Touyz RM 2008 Aldosterone and angiotensin II synergistically stimulate migration in vascular smooth muscle cells through c-Src-regulated redox-sensitive RhoA pathways. Arteriosclerosis, Thrombosis, and Vascular Biology 28 1511-1518. (doi:10.1161/ATVBAHA.108.168021)

Moura AM \& Worcel M 1984 Direct action of aldosterone on transmembrane $22 \mathrm{Na}$ efflux from arterial smooth muscle. Rapid and delayed effects. Hypertension 6 425-430. (doi:10.1161/01.HYP.6.3.425)

Mueller KB, Bender SB, Hong K, Yang Y, Aronovitz M, Jaisser F, Hill MA \& Jaffe IZ 2015 Endothelial mineralocorticoid receptors differentially contribute to coronary and mesenteric vascular function without modulating blood pressure. Hypertension 66 988-997. (doi:10.1161/ HYPERTENSIONAHA.115.06172)

Mulatero P, Monticone S, Bertello C, Viola A, Tizzani D, Iannaccone A, Crudo V, Burrello J, Milan A, Rabbia F, et al. 2013 Long-term cardioand cerebrovascular events in patients with primary aldosteronism. Journal of Clinical Endocrinology and Metabolism 98 4826-4833. (doi:10.1210/jc.2013-2805)

Mullins LJ, Kenyon CJ, Bailey MA, Conway BR, Diaz ME \& Mullins JJ 2015 Mineralocorticoid excess or glucocorticoid insufficiency: renal and metabolic phenotypes in a rat Hsd11b2 knockout model. Hypertension 66 667-673. (doi:10.1161/HYPERTENSIONAHA. $115.05262)$

Muto S, Nemoto J, Ohtaka A, Watanabe Y, Yamaki M, Kawakami K, Nagano K \& Asano Y 1996 Differential regulation of Na+-K+-ATPase gene expression by corticosteriods in vascular smooth muscle cells. American Journal of Physiology 270 C731-C739.

Mutoh A, Isshiki M \& Fujita T 2008 Aldosterone enhances ligandstimulated nitric oxide production in endothelial cells. Hypertension Research: Clinical and Experimental 31 1811-1820. (doi:10.1291/ hypres.31.1811)

Nagai Y, Miyata K, Sun GP, Rahman M, Kimura S, Miyatake A, Kiyomoto H, Kohno M, Abe Y, Yoshizumi M, et al. 2005 Aldosterone stimulates collagen gene expression and synthesis via activation of ERK1/2 in rat renal fibroblasts. Hypertension 46 1039-1045. (doi:10.1161/01.HYP.0000174593.88899.68)

Nagase M, Ayuzawa N, Kawarazaki W, Ishizawa K, Ueda K, Yoshida S \& Fujita T 2012 Oxidative stress causes mineralocorticoid receptor activation in rat cardiomyocytes: role of small GTPase Rac1. Hypertension 59 500-506. (doi:10.1161/ HYPERTENSIONAHA.111.185520)

Nagata D, Takahashi M, Sawai K, Tagami T, Usui T, Shimatsu A, Hirata Y \& Naruse M 2006 Molecular mechanism of the inhibitory effect of aldosterone on endothelial NO synthase activity. Hypertension $\mathbf{4 8}$ 165-171. (doi:10.1161/01.HYP.0000226054.53527.bb)

Nakamura TY, Iwata Y, Arai Y, Komamura K \& Wakabayashi S 2008 Activation of $\mathrm{Na}+/ \mathrm{H}+$ exchanger 1 is sufficient to generate $\mathrm{Ca} 2+$ signals that induce cardiac hypertrophy and heart failure. Circulation Research 103 891-899. (doi:10.1161/CIRCRESAHA.108.175141)

Nakamura T, Kataoka K, Fukuda M, Nako H, Tokutomi Y, Dong YF, Ichijo H, Ogawa H \& Kim-Mitsuyama S 2009 Critical role of apoptosis signal-regulating kinase 1 in aldosterone/salt-induced cardiac inflammation and fibrosis. Hypertension 54 544-551. (doi:10.1161/HYPERTENSIONAHA.109.135392)

Naray-Fejes-Toth A \& Fejes-Toth G 2000 The sgk, an aldosterone-induced gene in mineralocorticoid target cells, regulates the epithelial sodium channel. Kidney International $\mathbf{5 7}$ 1290-1294. (doi:10.1046/j.1523-1755.2000.00964.x)

Newfell BG, Iyer LK, Mohammad NN, McGraw AP, Ehsan A, Rosano G, Huang PL, Mendelsohn ME \& Jaffe IZ 2011 Aldosterone regulates vascular gene transcription via oxidative stress-dependent and -independent pathways. Arteriosclerosis, Thrombosis, and Vascular Biology 31 1871-1880. (doi:10.1161/ATVBAHA.111.229070)

Nishi M 2011 Dynamics of corticosteroid receptors: lessons from live cell imaging. Acta Histochemica et Cytochemica 44 1-7. (doi:10.1267/ ahc.10028)

Nishi M, Tanaka M, Matsuda K, Sunaguchi M \& Kawata M 2004 Visualization of glucocorticoid receptor and mineralocorticoid receptor interactions in living cells with GFP-based fluorescence resonance energy transfer. Journal of Neuroscience 24 4918-4927. (doi:10.1523/JNEUROSCI.5495-03.2004)

Nolly MB, Caldiz CI, Yeves AM, Villa-Abrille MC, Morgan PE, Amado Mondaca N, Portiansky EL, Chiappe de Cingolani GE, Cingolani HE \& Ennis IL 2014 The signaling pathway for aldosterone-induced mitochondrial production of superoxide anion in the myocardium. Journal of Molecular and Cellular Cardiology 67 60-68. (doi:10.1016/j. yjmcc.2013.12.004)

Oberfeld B, Ruffieux-Daidie D, Vitagliano JJ, Pos KM, Verrey F \& Staub O 2011 Ubiquitin-specific protease 2-45 (Usp2-45) binds to epithelial $\mathrm{Na}+$ channel (ENaC)-ubiquitylating enzyme Nedd4-2. American Journal of Physiology: Renal Physiology 301 F189-F196. (doi:10.1152/ ajprenal.00487.2010)

Oberleithner H, Weigt M, Westphale HJ \& Wang W 1987 Aldosterone activates $\mathrm{Na}+\mathrm{H}+$ exchange and raises cytoplasmic $\mathrm{pH}$ in target cells of the amphibian kidney. PNAS 84 1464-1468. (doi:10.1073/ pnas.84.5.1464)

Oberleithner H, Schneider SW, Albermann L, Hillebrand U, Ludwig T, Riethmuller C, Shahin V, Schafer C \& Schillers H 2003 Endothelial cell swelling by aldosterone. Journal of Membrane Biology 196 163-172. (doi:10.1007/s00239-003-0635-6)

Oberleithner H, Riethmuller C, Ludwig T, Hausberg M \& Schillers H 2006 Aldosterone remodels human endothelium. Acta Physiologica 187 305-312. (doi:10.1111/j.1748-1716.2006.01574.x)

Okoshi MP, Yan X, Okoshi K, Nakayama M, Schuldt AJ, O'Connell TD, Simpson PC \& Lorell BH 2004 Aldosterone directly stimulates cardiac myocyte hypertrophy. Journal of Cardiac Failure 10 511-518. (doi:10.1016/j.cardfail.2004.03.002)

Orlowski A, De Giusti VC, Ciancio MC, Espejo MS \& Aiello EA 2016 The cardiac electrogenic sodium/bicarbonate cotransporter (NBCe1) is activated by aldosterone through the $\mathrm{G}$ protein-coupled receptor 30 (GPR 30). Channels 10 428-434. (doi:10.1080/19336950.2016. 1195533)

Ouvrard-Pascaud A, Sainte-Marie Y, Benitah JP, Perrier R, Soukaseum C, Nguyen Dinh Cat A, Royer A, Le Quang K, Charpentier F, Demolombe S, et al. 2005 Conditional mineralocorticoid receptor expression in the heart leads to life-threatening arrhythmias. Circulation 111 3025-3033. (doi:10.1161/CIRCULATIONAHA. 104.503706)

Payvar F, DeFranco D, Firestone GL, Edgar B, Wrange O, Okret S, Gustafsson JA \& Yamamoto KR 1983 Sequence-specific binding of glucocorticoid receptor to MTV DNA at sites within and upstream of the transcribed region. Cell 35 381-392. (doi:10.1016/00928674(83)90171-X)

Pearce PT \& Funder JW 1988 Steroid binding to cardiac type I receptors: in vivo studies. Journal of Hypertension. Supplement 6 S131-S133. (doi:10.1097/00004872-198812040-00038)

Pearce D \& Yamamoto KR 1993 Mineralocorticoid and glucocorticoid receptor activities distinguished by nonreceptor factors at a 
composite response element. Science 259 1161-1165. (doi:10.1126/ science.8382376)

Pinto V, Pinho MJ, Hopfer U, Jose PA \& Soares-da-Silva P 2008 Oxidative stress and the genomic regulation of aldosterone-stimulated NHE1 activity in SHR renal proximal tubular cells. (Erratum appears in Mol Cell Biochem 2011357 423). Molecular and Cellular Biochemistry 310 191-201. (doi:10.1007/s11010-007-9680-6)

Pippal JB \& Fuller PJ 2008 Structure-function relationships in the mineralocorticoid receptor. Journal of Molecular Endocrinology $\mathbf{4 1}$ 405-413. (doi:10.1677/JME-08-0093)

Pitt B, Zannad F, Remme WJ, Cody R, Castaigne A, Perez A, Palensky J \& Wittes J 1999 The effect of spironolactone on morbidity and mortality in patients with severe heart failure. Randomized Aldactone Evaluation Study Investigators. New England Journal of Medicine 341 709-717. (doi:10.1056/NEJM199909023411001)

Pitt B, Remme W, Zannad F, Neaton J, Martinez F, Roniker B, Bittman R, Hurley S, Kleiman J \& Gatlin M 2003 Eplerenone, a selective aldosterone blocker, in patients with left ventricular dysfunction after myocardial infarction. New England Journal of Medicine $\mathbf{3 4 8}$ 1309-1321. (doi:10.1056/NEJMoa030207)

Pochynyuk O, Tong Q, Staruschenko A \& Stockand JD 2007 Binding and direct activation of the epithelial $\mathrm{Na}+$ channel $(\mathrm{ENaC})$ by phosphatidylinositides. Journal of Physiology 580 365-372. (doi:10.1113/jphysiol.2006.127449)

Prossnitz ER, Arterburn JB \& Sklar LA 2007 GPR30: a G protein-coupled receptor for estrogen. Molecular and Cellular Endocrinology 265-266 138-142. (doi:10.1016/j.mce.2006.12.010)

Qin W, Rudolph AE, Bond BR, Rocha R, Blomme EA, Goellner JJ, Funder JW \& Mcmahon EG 2003 Transgenic model of aldosteronedriven cardiac hypertrophy and heart failure. Circulation Research 93 69-76. (doi:10.1161/01.RES.0000080521.15238.E5)

Queisser N, Oteiza PI, Stopper H, Oli RG \& Schupp N 2011 Aldosterone induces oxidative stress, oxidative DNA damage and NF-kappaBactivation in kidney tubule cells. Molecular Carcinogenesis $\mathbf{5 0}$ 123-135. (doi:10.1002/mc.20710)

Quinkler M, Meyer B, Bumke-Vogt C, Grossmann C, Gruber U, Oelkers W, Diederich S \& Bahr V 2002 Agonistic and antagonistic properties of progesterone metabolites at the human mineralocorticoid receptor. European Journal of Endocrinology 146 789-799. (doi:10.1530/eje.0.1460789)

Quirk SJ, Gannell JE \& Funder JW 1983 Aldosterone-binding sites in pregnant and lactating rat mammary glands. Endocrinology 113 1812-1817. (doi:10.1210/endo-113-5-1812)

Rafestin-Oblin ME, Lombes M, Michiel JB, Michaud A \& Claire M 1984 Mineralocorticoid receptors in the epithelial cells of human colon and ileum. Journal of Steroid Biochemistry 20 311-315. (doi:10.1016/0022-4731(84)90223-1)

Revankar CM, Cimino DF, Sklar LA, Arterburn JB \& Prossnitz ER 2005 A transmembrane intracellular estrogen receptor mediates rapid cell signaling. Science 307 1625-1630. (doi:10.1126/ science.1106943)

Rickard AJ, Morgan J, Bienvenu LA, Fletcher EK, Cranston GA, Shen JZ, Reichelt ME, Delbridge LM \& Young MJ 2012 Cardiomyocyte mineralocorticoid receptors are essential for deoxycorticosterone/saltmediated inflammation and cardiac fibrosis. Hypertension 60 1443-1450. (doi:10.1161/HYPERTENSIONAHA.112.203158)

Rickard AJ, Morgan J, Chrissobolis S, Miller AA, Sobey CG \& Young MJ 2014 Endothelial cell mineralocorticoid receptors regulate deoxycorticosterone/salt-mediated cardiac remodeling and vascular reactivity but not blood pressure. Hypertension 63 1033-1040. (doi:10.1161/HYPERTENSIONAHA.113.01803)

Rigiracciolo DC, Scarpelli A, Lappano R, Pisano A, Santolla MF, Avino S, De Marco P, Bussolati B, Maggiolini M \& De Francesco EM 2016 GPER is involved in the stimulatory effects of aldosterone in breast cancer cells and breast tumor-derived endothelial cells. Oncotarget 7 94-111.
Rocha R, Martin-Berger CL, Yang P, Scherrer R, Delyani J \& McMahon E $2002 a$ Selective aldosterone blockade prevents angiotensin II/saltinduced vascular inflammation in the rat heart. Endocrinology $\mathbf{1 4 3}$ 4828-4836. (doi:10.1210/en.2002-220120)

Rocha R, Rudolph AE, Frierdich GE, Nachowiak DA, Kekec BK, Blomme EA, McMahon EG \& Delyani JA 2002b Aldosterone induces a vascular inflammatory phenotype in the rat heart. American Journal of Physiology: Heart and Circulatory Physiology 283 H1802-H1810. (doi:10.1152/ajpheart.01096.2001)

Rogerson FM, Brennan FE \& Fuller PJ 2004 Mineralocorticoid receptor binding, structure and function. Molecular and Cellular Endocrinology 217 203-212. (doi:10.1016/j.mce.2003.10.021)

Roskoski R Jr 2012 ERK1/2 MAP kinases: structure, function, and regulation. Pharmacological Research 66 105-143. (doi:10.1016/j. phrs.2012.04.005)

Rossi GP, Sacchetto A, Visentin P, Canali C, Graniero GR, Palatini P \& Pessina AC 1996 Changes in left ventricular anatomy and function in hypertension and primary aldosteronism. Hypertension $\mathbf{2 7}$ 1039-1045. (doi:10.1161/01.HYP.27.5.1039)

Rossi GP, Cesari M, Cuspidi C, Maiolino G, Cicala MV, Bisogni V, Mantero F \& Pessina AC 2013 Long-term control of arterial hypertension and regression of left ventricular hypertrophy with treatment of primary aldosteronism. (Erratum appears in Hypertension 201464 e7). Hypertension 62 62-69. (doi:10.1161/ HYPERTENSIONAHA.113.01316)

Rossier MF, Lenglet S, Vetterli L, Python M \& Maturana A 2008 Corticosteroids and redox potential modulate spontaneous contractions in isolated rat ventricular cardiomyocytes. Hypertension 52 721-728. (doi:10.1161/HYPERTENSIONAHA.108.114223)

Rozansky DJ, Cornwall T, Subramanya AR, Rogers S, Yang YF, David LL, Zhu X, Yang CL \& Ellison DH 2009 Aldosterone mediates activation of the thiazide-sensitive $\mathrm{Na}-\mathrm{Cl}$ cotransporter through an SGK1 and WNK4 signaling pathway. Journal of Clinical Investigation 119 2601-2612. (doi:10.1172/JCI38323)

Rozengurt E, Rey O \& Waldron RT 2005 Protein kinase D signaling. Journal of Biological Chemistry 280 13205-13208. (doi:10.1074/jbc. R500002200)

Rude MK, Duhaney TA, Kuster GM, Judge S, Heo J, Colucci WS, Siwik DA \& Sam F 2005 Aldosterone stimulates matrix metalloproteinases and reactive oxygen species in adult rat ventricular cardiomyocytes. Hypertension 46 555-561. (doi:10.1161/01.HYP.0000176236.55322.18)

Santillo M, Colantuoni A, Mondola P, Guida B \& Damiano S 2015 NOX signaling in molecular cardiovascular mechanisms involved in the blood pressure homeostasis. Frontiers in Physiology 6194. (doi:10.3389/fphys.2015.00194)

Savard S, Amar L, Plouin PF \& Steichen O 2013 Cardiovascular complications associated with primary aldosteronism: a controlled cross-sectional study. Hypertension 62 331-336. (doi:10.1161/ HYPERTENSIONAHA.113.01060)

Schiffrin EL, Franks DJ \& Gutkowska J 1985 Effect of aldosterone on vascular angiotensin II receptors in the rat. Canadian Journal of Physiology and Pharmacology 63 1522-1527. (doi:10.1139/y85-250)

Schneider SW, Yano Y, Sumpio BE, Jena BP, Geibel JP, Gekle M \& Oberleithner H 1997 Rapid aldosterone-induced cell volume increase of endothelial cells measured by the atomic force microscope. Cell Biology International 21 759-768. (doi:10.1006/cbir.1997.0220)

Schonbeck U, Mach F \& Libby P 1998 Generation of biologically active IL-1 beta by matrix metalloproteinases: a novel caspase-1independent pathway of IL-1 beta processing. Journal of Immunology $1613340-3346$.

Sechi LA, Novello M, Lapenna R, Baroselli S, Nadalini E, Colussi GL \& Catena C 2006 Long-term renal outcomes in patients with primary aldosteronism. JAMA 295 2638-2645. (doi:10.1001/jama.295.22.2638)

Shen JZ, Morgan J, Tesch GH, Fuller PJ \& Young MJ 2014 CCL2dependent macrophage recruitment is critical for mineralocorticoid

Published by Bioscientifica Ltd. 
receptor-mediated cardiac fibrosis, inflammation, and blood pressure responses in male mice. Endocrinology 155 1057-1066. (doi:10.1210/ en.2013-1772)

Shen JZ, Morgan J, Tesch GH, Rickard AJ, Chrissobolis S,

Drummond GR, Fuller PJ \& Young MJ 2016 Cardiac tissue injury and remodeling is dependent upon MR regulation of activation pathways in cardiac tissue macrophages. Endocrinology 157 3213-3223. (doi:10.1210/en.2016-1040)

Shibata S, Nagase M, Yoshida S, Kawarazaki W, Kurihara H, Tanaka H, Miyoshi J, Takai Y \& Fujita T 2008 Modification of mineralocorticoid receptor function by Rac1 GTPase: implication in proteinuric kidney disease. Nature Medicine 14 1370-1376. (doi:10.1038/nm.1879)

Shibata S, Mu S, Kawarazaki H, Muraoka K, Ishizawa K, Yoshida S, Kawarazaki W, Takeuchi M, Ayuzawa N, Miyoshi J, et al. 2011 Rac1 GTPase in rodent kidneys is essential for salt-sensitive hypertension via a mineralocorticoid receptor-dependent pathway. Journal of Clinical Investigation 121 3233-3243. (doi:10.1172/JCI43124)

Snyder PM, Olson DR \& Thomas BC 2002 Serum and glucocorticoidregulated kinase modulates Nedd4-2-mediated inhibition of the epithelial Na+ channel. Journal of Biological Chemistry 277 5-8. (doi:10.1074/jbc.C100623200)

Sobieszczyk P, Borlaug Barry A, Gornik Heather L, Knauft Wesley D \& Beckman Joshua A 2010 Glycyrrhetinic acid attenuates vascular smooth muscle vasodilatory function in healthy humans. Clinical Science 119 437-442. (doi:10.1042/CS20100087)

Soundararajan R, Wang J, Melters D \& Pearce D 2010 Glucocorticoidinduced Leucine zipper 1 stimulates the epithelial sodium channel by regulating serum- and glucocorticoid-induced kinase 1 stability and subcellular localization. Journal of Biological Chemistry $\mathbf{2 8 5}$ 39905-39913. (doi:10.1074/jbc.M110.161133)

Soundararajan R, Ziera T, Koo E, Ling K, Wang J, Borden SA \& Pearce D 2012 Scaffold protein connector enhancer of kinase suppressor of Ras isoform 3 (CNK3) coordinates assembly of a multiprotein epithelial sodium channel (ENaC)-regulatory complex. Journal of Biological Chemistry 287 33014-33025. (doi:10.1074/jbc. M112.389148)

Staruschenko A, Patel P, Tong Q, Medina JL \& Stockand JD 2004 Ras activates the epithelial $\mathrm{Na}(+)$ channel through phosphoinositide 3-OH kinase signaling. Journal of Biological Chemistry 279 37771-37778. (doi:10.1074/jbc.M402176200)

Stas S, Whaley-Connell A, Habibi J, Appesh L, Hayden MR, Karuparthi PR, Qazi M, Morris EM, Cooper SA, Link CD, et al. 2007 Mineralocorticoid receptor blockade attenuates chronic overexpression of the renin-angiotensin-aldosterone system stimulation of reduced nicotinamide adenine dinucleotide phosphate oxidase and cardiac remodeling. Endocrinology 148 3773-3780. (doi:10.1210/en.2006-1691)

Stockand JD \& Meszaros JG 2003 Aldosterone stimulates proliferation of cardiac fibroblasts by activating Ki-RasA and MAPK1/2 signaling. American Journal of Physiology: Heart and Circulatory Physiology 284 H176-H184. (doi:10.1152/ajpheart.00421.2002)

Sugiyama T, Yoshimoto T, Tsuchiya K, Gochou N, Hirono Y, Tateno T, Fukai N, Shichiri M \& Hirata Y 2005 Aldosterone induces angiotensin converting enzyme gene expression via a JAK2dependent pathway in rat endothelial cells. Endocrinology 146 3900-3906. (doi:10.1210/en.2004-1674)

Takeda M, Tatsumi T, Matsunaga S, Hayashi H, Kimata M, Honsho S, Nishikawa S, Mano A, Shiraishi J, Yamada H, et al. 2007 Spironolactone modulates expressions of cardiac mineralocorticoid receptor and 11beta-hydroxysteroid dehydrogenase 2 and prevents ventricular remodeling in post-infarct rat hearts. Hypertension Research: Clinical and Experimental 30 427-437. (doi:10.1291/ hypres.30.427)

Tarjus A, Belozertseva E, Louis H, El Moghrabi S, Labat C, Lacolley P, Jaisser F \& Galmiche G 2015a Role of smooth muscle cell mineralocorticoid receptor in vascular tone. Pflugers Archiv: European
Journal of Physiology 467 1643-1650. (doi:10.1007/s00424-0141616-x)

Tarjus A, Martinez-Martinez E, Amador C, Latouche C, El Moghrabi S, Berger T, Mak TW, Fay R, Farman N, Rossignol P, et al. 2015b Neutrophil gelatinase-associated lipocalin, a novel mineralocorticoid biotarget, mediates vascular profibrotic effects of mineralocorticoids. Hypertension 66 158-166. (doi:10.1161/

HYPERTENSIONAHA.115.05431)

Terada Y, Ueda S, Hamada K, Shimamura Y, Ogata K, Inoue K, Taniguchi Y, Kagawa T, Horino T \& Takao T 2012 Aldosterone stimulates nuclear factor-kappa B activity and transcription of intercellular adhesion molecule- 1 and connective tissue growth factor in rat mesangial cells via serum- and glucocorticoid-inducible protein kinase-1. Clinical and Experimental Nephrology 16 81-88. (doi:10.1007/s10157-011-0498-x)

Thomas P, Pang Y, Filardo EJ \& Dong J 2005 Identity of an estrogen membrane receptor coupled to a $G$ protein in human breast cancer cells. Endocrinology 146 624-632. (doi:10.1210/en.2004-1064)

Tsai CT, Chiang FT, Tseng CD, Hwang JJ, Kuo KT, Wu CK, Yu CC, Wang YC, Lai LP \& Lin JL 2010 Increased expression of mineralocorticoid receptor in human atrial fibrillation and a cellular model of atrial fibrillation. Journal of the American College of Cardiology 55 758-770. (doi:10.1016/j.jacc.2009.09.045)

Tsai CF, Yang SF, Chu HJ \& Ueng KC 2013 Cross-talk between mineralocorticoid receptor/angiotensin II type 1 receptor and mitogen-activated protein kinase pathways underlies aldosteroneinduced atrial fibrotic responses in HL-1 cardiomyocytes. International Journal of Cardiology 169 17-28. (doi:10.1016/j. ijcard.2013.06.046)

Turchin A, Guo CZ, Adler GK, Ricchiuti V, Kohane IS \& Williams GH 2006 Effect of acute aldosterone administration on gene expression profile in the heart. Endocrinology 147 3183-3189. (doi:10.1210/ en.2005-1674)

Ueda K, Fujiki K, Shirahige K, Gomez-Sanchez CE, Fujita T, Nangaku M \& Nagase M 2014 Genome-wide analysis of murine renal distal convoluted tubular cells for the target genes of mineralocorticoid receptor. Biochemical and Biophysical Research Communications $\mathbf{4 4 5}$ 132-137. (doi:10.1016/j.bbrc.2014.01.125)

Uhrenholt TR, Schjerning J, Hansen PB, Norregaard R, Jensen BL, Sorensen GL \& Skott O 2003 Rapid inhibition of vasoconstriction in renal afferent arterioles by aldosterone. Circulation Research $\mathbf{9 3}$ 1258-1266. (doi:10.1161/01.RES.0000106135.02935.E1)

Usher MG, Duan SZ, Ivaschenko CY, Frieler RA, Berger S, Schutz G, Lumeng CN \& Mortensen RM 2010 Myeloid mineralocorticoid receptor controls macrophage polarization and cardiovascular hypertrophy and remodeling in mice. Journal of Clinical Investigation 120 3350-3364. (doi:10.1172/JCI41080)

Vallon V, Wyatt AW, Klingel K, Huang DY, Hussain A, Berchtold S, Friedrich B, Grahammer F, Belaiba RS, Gorlach A, et al. 2006 SGK1dependent cardiac CTGF formation and fibrosis following DOCA treatment. Journal of Molecular Medicine 84 396-404. (doi:10.1007/ s00109-005-0027-z)

Vinturache AE \& Smith FG 2014 Angiotensin type 1 and type 2 receptors during ontogeny: cardiovascular and renal effects. Vascular Pharmacology 63 145-154. (doi:10.1016/j.vph.2014.11.001)

Walczak C, Gaignier F, Gilet A, Zou F, Thornton SN \& Ropars A 2011 Aldosterone increases VEGF-A production in human neutrophils through PI3K, ERK1/2 and p38 pathways. Biochimica et Biophysica Acta 1813 2125-2132. (doi:10.1016/j.bbamcr.2011.07.010)

Waldinger T, Seaton JF \& Harrison TS 1977 Blood pressure vulnerability to volume contraction: regulation by adrenal cortical hormones. American Journal of Physiology 233 R239-R242.

Wang J, Barbry P, Maiyar AC, Rozansky DJ, Bhargava A, Leong M, Firestone GL \& Pearce D 2001 SGK integrates insulin and mineralocorticoid regulation of epithelial sodium transport. American Journal of Physiology: Renal Physiology 280 F303-F313. 
Wang J, Yu L, Solenberg PJ, Gelbert L, Geringer CD \& Steinberg MI 2002 Aldosterone stimulates angiotensin-converting enzyme expression and activity in rat neonatal cardiac myocytes. Journal of Cardiac Failure 8 167-174. (doi:10.1054/jcaf.2002.125369)

Wehling M, Christ M \& Theisen K 1991 High affinity aldosterone binding to plasma membrane rich fractions from mononuclear leukocytes: is there a membrane receptor for mineralocorticoids? Biochemical and Biophysical Research Communications 181 1306-1312. (doi:10.1016/0006-291X(91)92081-T)

Yamada M, Kushibiki M, Osanai T, Tomita H \& Okumura K 2008 Vasoconstrictor effect of aldosterone via angiotensin II type 1 (AT1) receptor: possible role of AT1 receptor dimerization. Cardiovascular Research 79 169-178. (doi:10.1093/cvr/cvn064)

Yang J \& Young MJ 2009 The mineralocorticoid receptor and its coregulators. Journal of Molecular Endocrinology 43 53-64. (doi:10.1677/JME-09-0031)

Ye P, Kenyon CJ, MacKenzie SM, Jong AS, Miller C, Gray GA, Wallace A, Ryding AS, Mullins JJ, McBride MW, et al. 2005 The aldosterone synthase (CYP11B2) and 11beta-hydroxylase (CYP11B1) genes are not expressed in the rat heart. Endocrinology 146 5287-5293. (doi:10.1210/en.2005-0370)

Yim HE, Yoo KH, Bae IS, Jang GY, Hong YS \& Lee JW 2009 Aldosterone regulates cellular turnover and mitogen-activated protein kinase family expression in the neonatal rat kidney. Journal of Cellular Physiology 219 724-733. (doi:10.1002/jcp.21723)

Ying W $2008 \mathrm{NAD+} / \mathrm{NADH}$ and NADP+/NADPH in cellular functions and cell death: regulation and biological consequences. Antioxidants and Redox Signaling 10 179-206. (doi:10.1089/ars.2007.1672)

Yoshimura M, Nakamura S, Ito T, Nakayama M, Harada E, Mizuno Y, Sakamoto T, Yamamuro M, Saito Y, Nakao K, et al. 2002 Expression of aldosterone synthase gene in failing human heart: quantitative analysis using modified real-time polymerase chain reaction. Journal of Clinical Endocrinology and Metabolism 87 3936-3940. (doi:10.1210/ jcem.87.8.8731)
Young M \& Funder J 2003 Mineralocorticoid action and sodiumhydrogen exchange: studies in experimental cardiac fibrosis. Endocrinology 144 3848-3851. (doi:10.1210/en.2003-0039)

Zannad F, Mcmurray JJ, Krum H, Van Veldhuisen DJ, Swedberg K, Shi H, Vincent J, Pocock SJ \& Pitt B 2011 Eplerenone in patients with systolic heart failure and mild symptoms. New England Journal of Medicine 364 11-21. (doi:10.1056/NEJMoa1009492)

Zecevic M, Heitzmann D, Camargo SM \& Verrey F 2004 SGK1 increases $\mathrm{Na}, \mathrm{K}-\mathrm{ATP}$ cell-surface expression and function in Xenopus laevis oocytes. Pflugers Archiv: European Journal of Physiology 448 29-35. (doi:10.1007/s00424-003-1222-9)

Zendaoui A, Lachance D, Roussel E, Couet J \& Arsenault M 2012 Effects of spironolactone treatment on an experimental model of chronic aortic valve regurgitation. Journal of Heart Valve Disease $\mathbf{2 1}$ 478-486.

Zennaro MC, Le Menuet D \& Lombes M 1996 Characterization of the human mineralocorticoid receptor gene 5'-regulatory region: evidence for differential hormonal regulation of two alternative promoters via nonclassical mechanisms. Molecular Endocrinology 10 1549-1560. (doi:10.1210/me.10.12.1549)

Zhang L, Cui R, Cheng X \& Du J 2005 Antiapoptotic effect of serum and glucocorticoid-inducible protein kinase is mediated by novel mechanism activating I\{kappa\}B kinase. Cancer Research 65 457-464.

Zhang W, Xia X, Reisenauer MR, Rieg T, Lang F, Kuhl D, Vallon V \& Kone BC 2007 Aldosterone-induced Sgk1 relieves Dot1a-Af9mediated transcriptional repression of epithelial $\mathrm{Na}+$ channel alpha. Journal of Clinical Investigation 117 773-783. (doi:10.1172/ JCI29850)

Zhou ZH \& Bubien JK 2001 Nongenomic regulation of ENaC by aldosterone. American Journal of Physiology: Cell Physiology $\mathbf{2 8 1}$ C1118-C1130.

Zhuang S \& Liu N 2014 EGFR signaling in renal fibrosis. Kidney International Supplements 4 70-74. (doi:10.1038/kisup.2014.13)

Received in final form 17 October 2016

Accepted 6 November 2016

Accepted Preprint published online 7 November 2016 http://jme.endocrinology-journals.org DOI: 10.1530/JME-15-0318
() 2017 Society for Endocrinology Printed in Great Britain 